\title{
تقاعس الطلاب في أداء الواجبات البيتية
}

\section{أ.م. د. عفاف حسن محمد شبر}

الجامعة المستنصرية -كلية التربية

\section{ملخص البحث باللغة العربية-:}

يستهذف هذا البحث التعرف على أسباب نقاعس الطلاب في أداء الواجبات البيتية من وجهة نظر الطلاب المدرسين, لذا تتبع أهميته من أهمية الواجبات البيتية نفسها بوصفها وسيلة من وسائل التقويم ومقياس لما فهمه الطلبة من فن فئل الموضوع بوصفه تطبيقاً عملياً عليه.

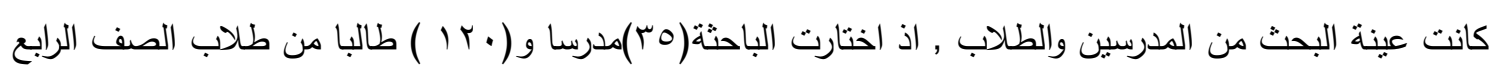
الإعدادي.

تمثلت أداة البحث باستبانة بواقع(· ·) فقرة موزعة على مجالين هما مجال المدرسين ومجال الطلاب قامت الباحثة

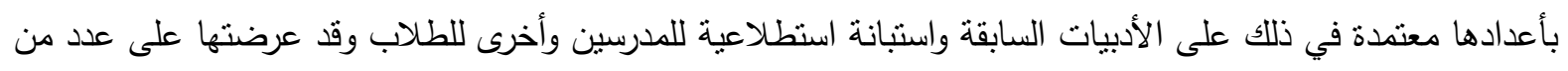
الخبراء في التربية وطرائق التدريس لأثبات صدقها ثم طبقتها على العينة وعاملت البيانات إحصائياً بعدد من الوسائل

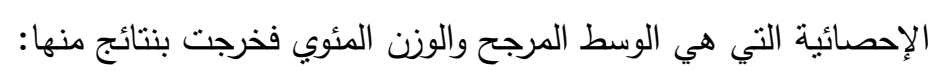

ان من أسباب تقاعس الطلاب عدم الاستخدام الصحيح للتقنيات الحديثة من الموبايل والأنترنيت بل المبالغة في

$$
\text { ذللك وضياع الوقت فيه. }
$$

• عدم متابعة المعلم والمدرسة لما ينجزه الطالب من واجبات مما يبعدهم عن الشعور بالمسؤولية اتجاهها.

$$
\begin{aligned}
& \text { • عدم تقرغ بعض الطلاب لأداء الواجبات البيتية لانشغالهم بالعمل بعد الدوام المدرسي. } \\
& \text { • روتين الواجب البيتي مما يبعث الملل في نفوس الطلاب. } \\
& \text { • للاروس الخصوصية تأثير سلبي في أداء الواجبات. }
\end{aligned}
$$


مما تقدم استتتج الباحثة ان لكل من الطالب والمدرس أثراً كبيرا في هذا التقاعس مما يتطلب ادراك كل منهما

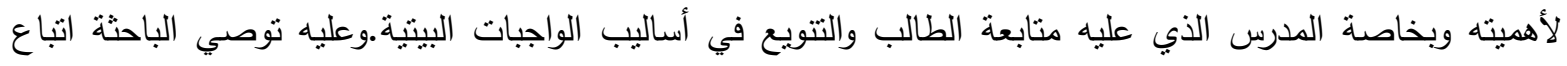

برنامج منظم في الواجبات البيتية وذلك بالمتابعة المستمرة وتحديد درجة لها وتضمين الأسئلة الامتحانية عددا مما تتضمنها الواجبات البيتية من أسئلة.

الملخص باللغة الإنكليزية:

Summary Arabic search: -

This research aims to identify the reasons for the failure of students in the performance of homework from the point of view of teachers and students, so its importance stems from the importance of homework itself as a means of evaluation and measure what students understand the topic as a practical application.

The research sample of teachers and students, as the researcher has chosen (35) teachers and (120) students from fourth grade preparatory.

Represented search tool identifying by (20) items distributed on two areas the teachers and the students, the researcher prepared by relying on literature past and identifying prospective teachers and other students have presented a number of experts in education and teaching methods to prove its sincerity and then applied to the sample and treated data statistically in a number of ways that are statistical middle percentage weight showed the results:

1-That the reasons for the failure of students lack the proper use of modern technology of Mobile and the Internet, but exaggerate the loss of time in it.

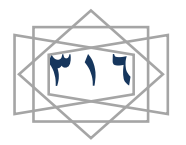


2-Not follow the teacher and the school to accomplish the student of the duties which keep them away from the sense of responsibility direction.

3-Not unloaded some students to perform homework for their preoccupation with work after school hours.

4-Homework routine is a matter boredom in the hearts of students.

5-Private lessons a negative impact on the performance of duties.

Foregoing concluded researcher that both the student and the teacher a big role in this failure, which requires awareness of their respective importance and especially a teacher who it follow the student and diversification in styles homework. Therefore recommends researcher follow a structured program in homework and that follow-up continuing and determine the degree of her and included questions test scores a number which included homework questions. 


\section{الفصل الاول}

\section{مشكلة البحث:}

لكل درس من الدروس خطوات منظمة يتبعها المدرس لتحقيق أهدافه ولابد من التخطبط لها مسبقاً

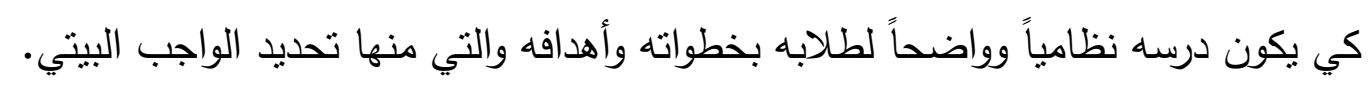
تعد الواجبات البيتية خطوة مهمة من خطوات الدرس - من خلالها -يمكن للمدرس أو المعلم ان

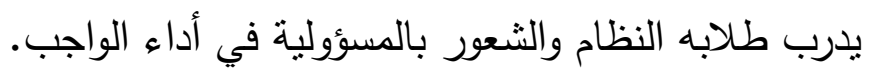

وقد يختلف المدرسون في موقفهم من هذه الخطوة سواءاً في ما تتضدنه من تكليف للطلبة,أو الوقت

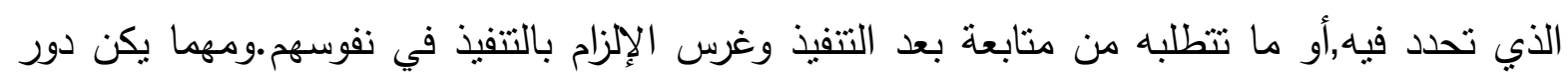

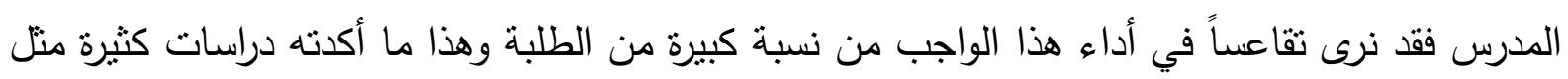

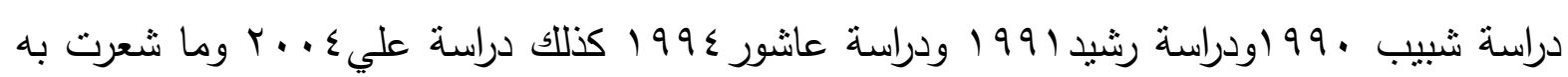

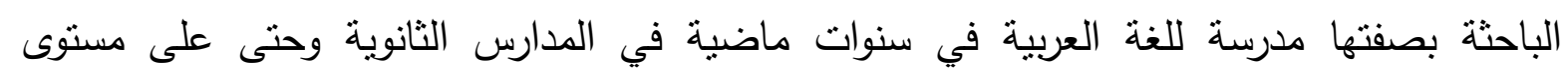

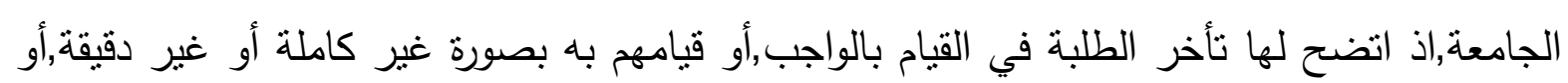

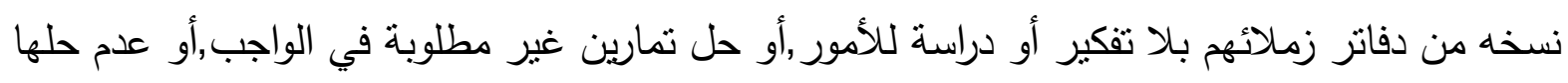

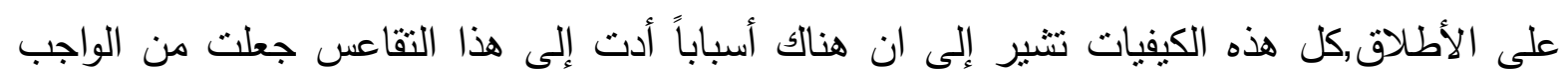
البيتي مشكلة أو عقبة أمام بعض الطلبة مما دفع الباحثة إلى دراسة هذه المشكلة للوقوف على ألى أسبابها والمساهمة في حلها.

وتتركز مشكلة البحث الحالي في الجواب عن التساؤل الاتي -:ماهي أسباب تقاعس الطلاب في

أداء الواجبات البيتية ؟ وما مقترحاتك لعلاجها ؟ 


\section{أهمية البحث والحاجة البه:}

تتجلى أهمية الواجب البيتي كونه فرصة بغتتمها المدرس لتوجيه الفعالية التعليمية,وهو جزء أساس من الخطة,وعلى المدرس ان يعالجه بالقدر الكافي,وان يخصص الوقت المناسب في خطة الدرس والا

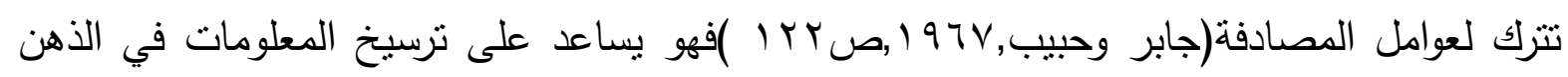
ويدرب الطلبة على العمل الحقيقي والمنظم روالتفكير المتواصل ,والمستقل (الحصري,190^19 ,صعء • ( ) فهو من الوسائل المهمة في تدريس المواد المختلفة لما له من دور في تعميق فهم الطلاب للاروس التي يتلقونها في المدرسة, وتثنيت المعلومات في الذاكرة والإفادة منها في الحياة العلمية.

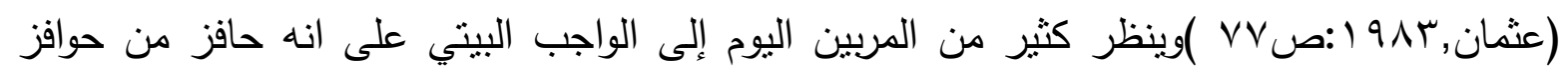
التعليم ودافع من دوافعه ,وعامل من عوامل تفعيله روحلقة من حلقات سلسلة تربوية محكمة منظمة مخططة ذلك لأنه يحقق أهدافاً متعددة يمكن ان تفيد منها في دروس اللغة بوصفها وسيلة من وسائل دورئ التعزيز, والتتبيت لما يتعلمونه داخل الصف, واستكمال ما عجز وقت الحصة عن استيفائه (البجة,، . . . r ,ص rه . (ويعطي الواجب البيتي المدرس صورة صادقة عن إنجازات طلابه,ومستوياتهم وتقدمهر, ويتيح له الفرصة لاكتثاف مواهبهم وقدراتهم, والتخطيط لتتميتها , واكتثاف صعوبات المتأخرين منهم, والتخطيط لما يلزم من عمل علاجي (الحسون, 1991 ,ص ب)كذلك تتجلى أهمية البحث الحالي في انه يتتاول موضوعاً قلّ تتاوله بالدراسة والبحث في العراق بخاصة- على حد علم الباحثة-وبذا يمكن ان

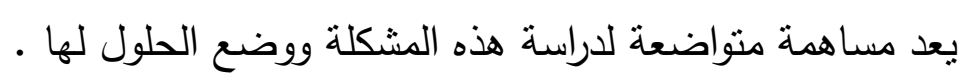

هدف البحث: يهذف البحث إلى:

تعرف أسباب تقاعس الطلاب في أداء الواجبات البيتية في اللغة العربية من خلال الهدفين الفرعيين الآتين :-

ا - تعرف الأسباب المتعلقة بكل من الطلاب والمدرسين. 


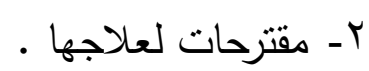

حدود البحث:

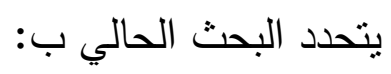

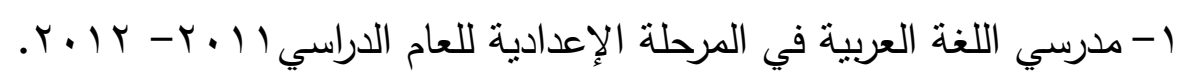
r- طلاب الصف الرابع من المرحلة الإعدادية.

\section{تحدبد المصطحات:}

ستقوم الباحثة بتعريف المصطلحين الآتيين النقاعس ,الواجبات البيتية

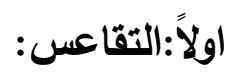

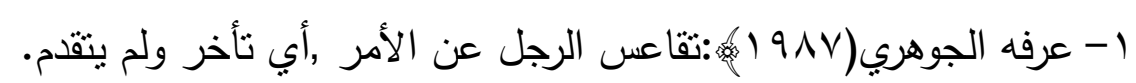

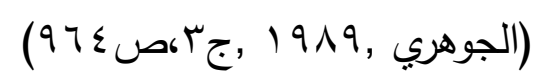

r- عرفه الفراهيدي(919 ())ثاعس فلان:اذا لم ينفذ, ولم يمض لما كلف.

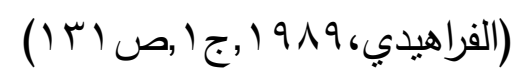

التعريف النظري:- التقاعس هو إهمال الطالب أو تهاونه أو تقصيره في أداء ما يكلفه به المدرس من واجبات خارج حدود الصف الدراسي .

التعريف الإجرائي:- هو الدرجة التي يحصل عليها الطالب من خلال تعرضه لمقياس اداة البحث.

ب- بانيا:الواجبات البيتية :

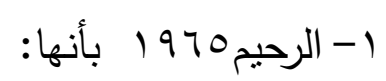




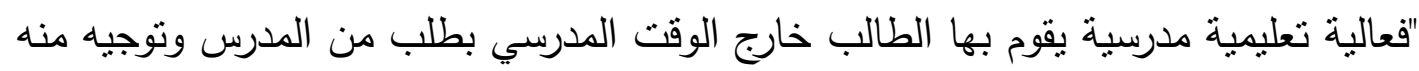

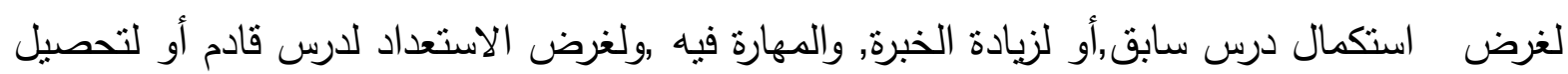
معلومات عن موضوع , أو لاكتساب خبرة ومر انه في تحميص المعلومات وتعليلها." (الرحيم , 1970 , ل ص.

$$
\text { r- (ال ياسين (9 ( ) ) بأنها: }
$$

" فعاليات تعليمية موجهة ينهمك الطلاب فيها بنباهة وهمة ورغبة وذللك بفضل ما يطلبه الددرس

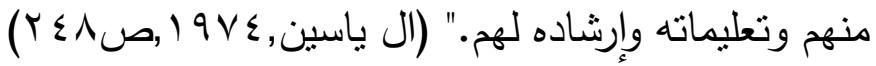

$$
\begin{aligned}
& \text { r- ابو حويج ( · . . r)بأنها: }
\end{aligned}
$$

"الفعالية التعليمية التي يوجه الطلاب القيام بها خارج الصف من المدرسين لمساعدتهم في

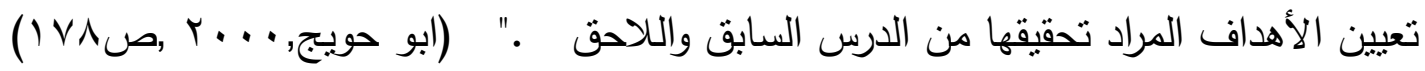

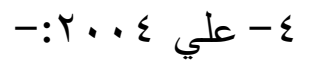

عملية أداء إنجاز أو فعالية يكلف المعلم بها الطلبة خارج المدرسة, وهي متممة لفعالية صفية

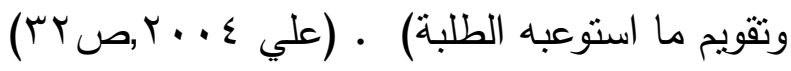

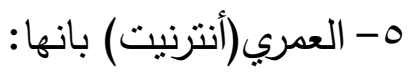

أ-احدى وسائل تعزيز التعلم وقياس العملية التعليمية التي يعتمد عليها التقويم في الحكم على ددى تقدم الطالب ونمو مسنواه العلمي. ب-تلك الأعمال المتتوعة التي يكلف بها المعلم طلابه لأدائها خارج الصف الدراسي. ج-مهمات يكلف بها المعلمون طلابهم اذ يطلب منهم إنجازها في غير ساعات الدوام الددرسي. 
د-أي نشاط موجه يقوم به الطالب خارج الصف الدراسي بهدف التمكن من المادة العلمية (www.riyadhedu.gov.sa/alan/fnt...am/wagibat.doc)

\section{التعريف النظري للواجبات البيتية:}

هو ما يكلف الطلاب بأدائه خارج المدرسة بوصفه وسيلة من وسائل تقويم ما استوعبوه من

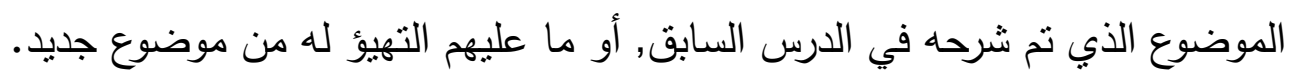
الفصل الثاني جوانب نظرية ودراسات سابقة

$$
\text { أولاً - -:جوانب نظرية }
$$

الواجبات اليتية بين الماضي والحاضر:

لم تعد الواجبات البيتية وليدة الحاضر وإنما استعملت من زمن بعيد في المدارس وتتاولها المربون بمفاهيم متعددة فمنهم من سماها بالوظائف المنزلية, أو النشاط البيتي أو التعيينات..... الخ ولعل التهن اكترها

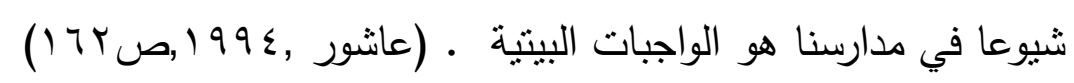

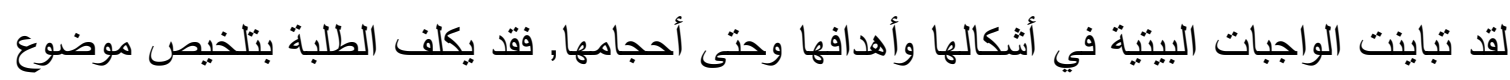

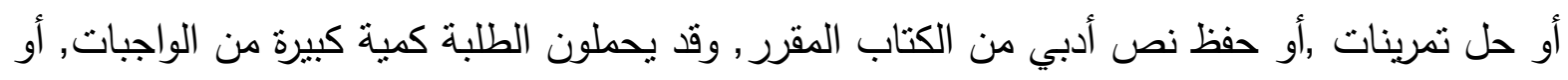

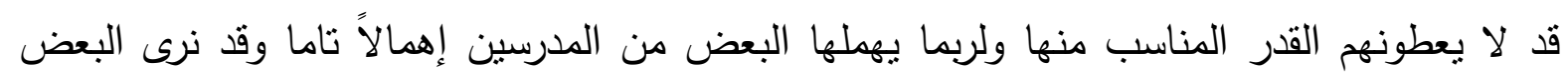

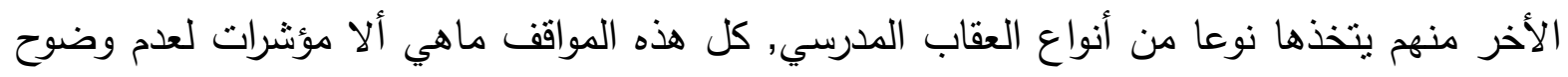

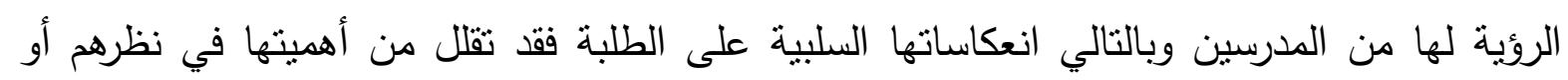

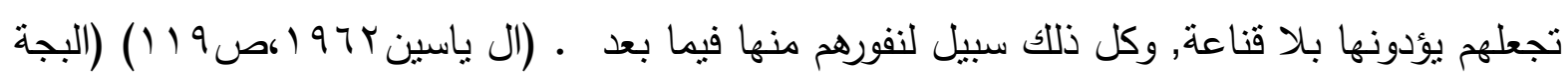

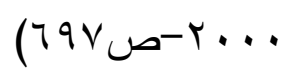


وقد يرى اللقاني 19 ان ان الواجبات البيتية لا نستغل ألا القليل من طاقات المتعلمين وإمكانياتهر,

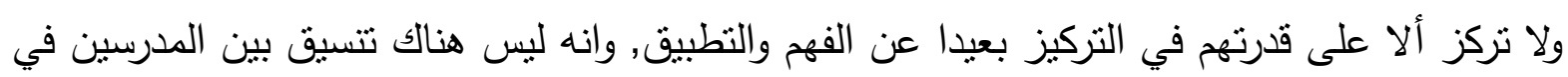

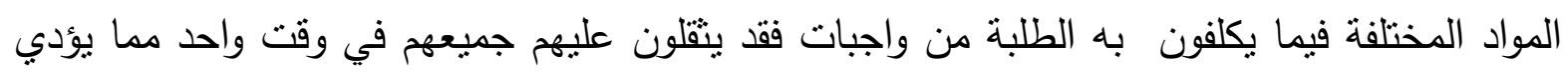

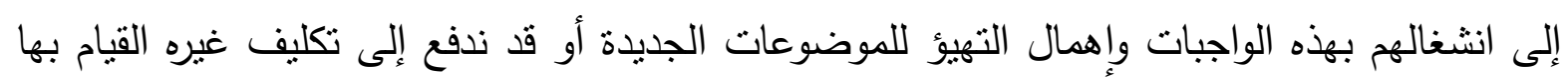

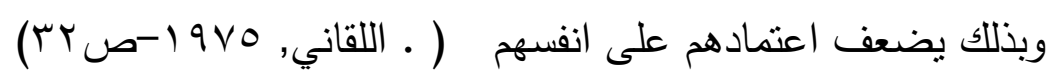

أما الريانـ1919 فقد يرى ان النظرة إلى الواجبات البيتية قد تغيرت عما عليه سابقا, اذ أصيح

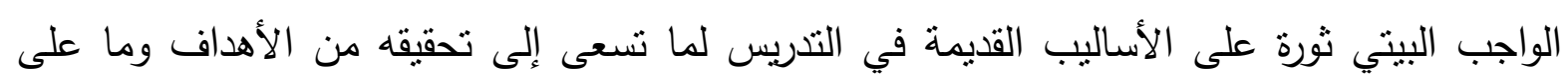

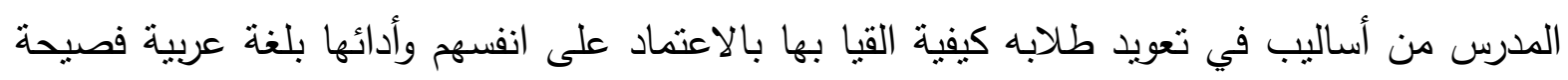

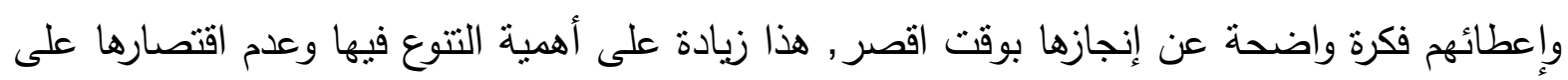
ما في الكتاب الددرسي المقرر من واجبات أو تمرينات وبذلك يصبح الواجب البيتي سبيلا أو وسيلة

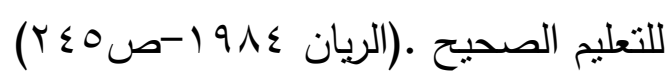

مما تقام نرى التربوبين بين مؤيد ومعارض للواجبات البيتية فقد يرى مؤيدوها ان فيها تأثيراً

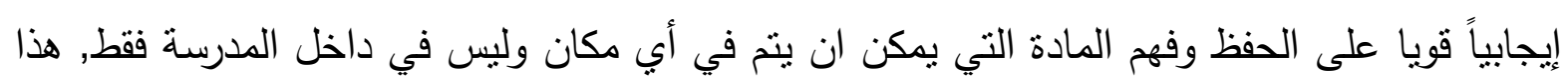

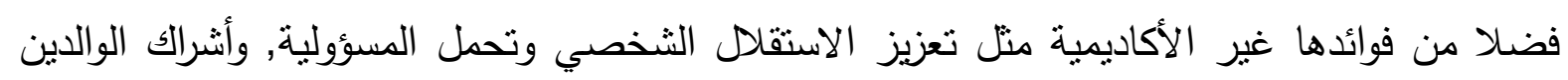

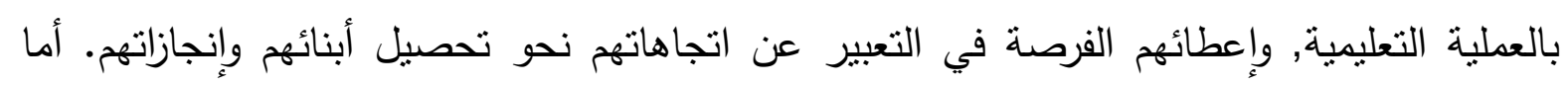

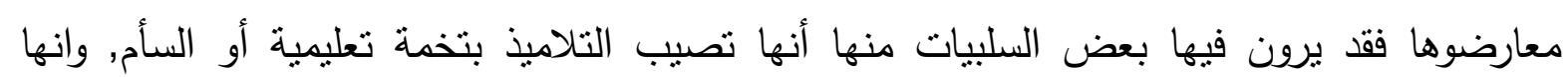

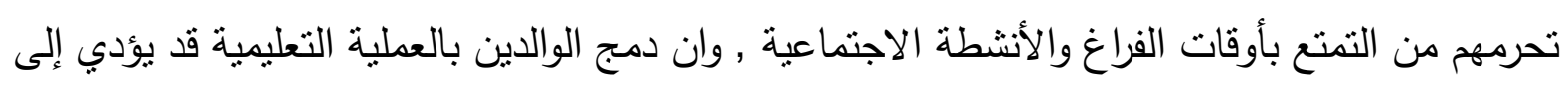

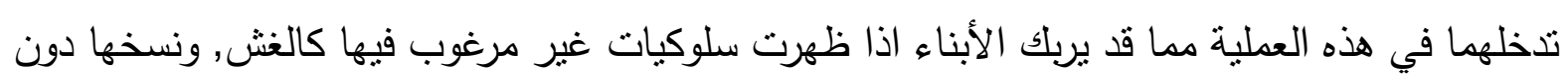

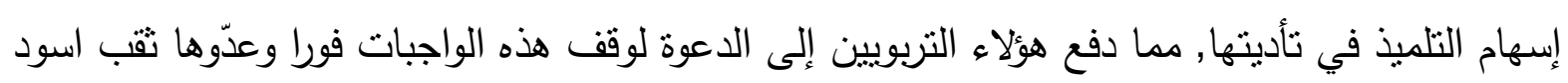

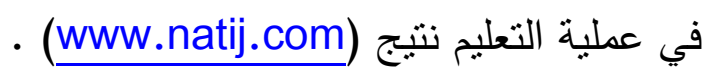




\section{ضوإط الواجيات البيتية أو شروطها:}

لابد من مراعاة عدد من الضوابط في تحديد الواجبات البيتية أو إعطائها للطلبة كي تصبح قادرة

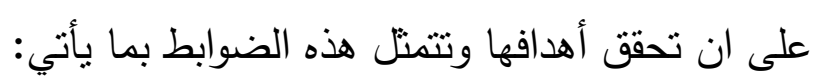

• ان يخطط لها المعلم سواءا كان من ناحية ما تتضمنه من أنتطة, أو ما يتبعه الطالب من طريقة في تتفيذها, وان يشرك الطالب في هذا التخطيط, وان يزوده بما يلزم من توجيهات. (

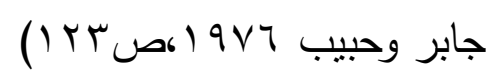

• ان يراعى الفروق الفردية فيما يكلفهم به من واجبات اذ تكون متتاسبة في طولها وقصرها ونوعها

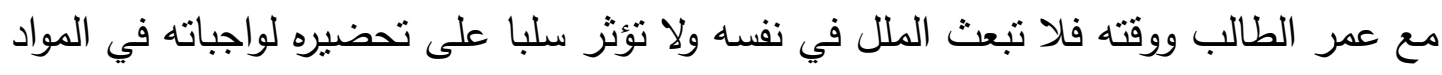

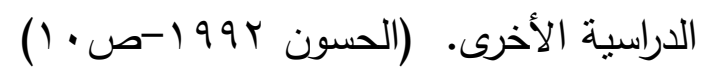

• ان ينوع في الواجبات البيتية ولا يقتصر على ما في الكتاب الددرسي من تدريبات وأنشطة وبذلك

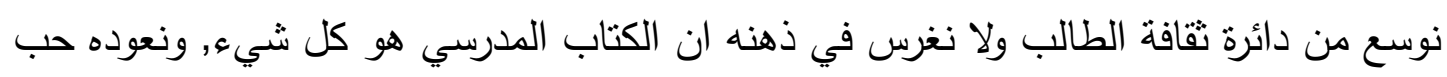

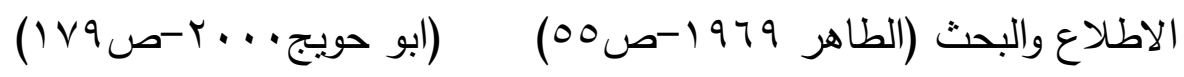

• ان لا يضيع المعلم جهد الطالب في إداء الواجبات بعدم متابعته له وإنما عليه بالمتابعة المستمرة

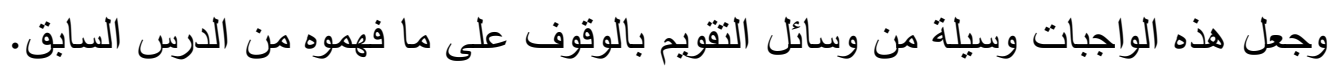
• ان يكون الواجب البيتي محددا كي يتضح ما مطلوب منه بدقة ولا يضيع وقته وجهده في أمور

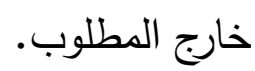

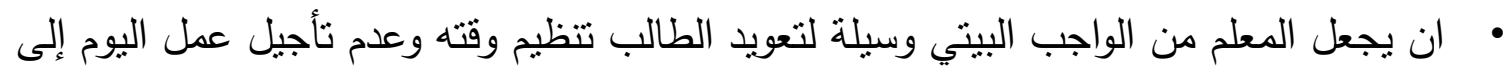
غد, وبذلك بان يعطيه الوقت الكافي لأدائه(ابو مرام). 
• ان لا يقتصر على الأداء الكتابي أو الحفظ والاستظهار فقطوإنما علبه الربط بين الجانبين النظري والعملي, وبذللك ننمي تفكير الطالب وندرب حواسه كافة على العمل. لأل

• ان يكون المعلم على تواصل مع أولياء أمور الطلبة فيوعيهم بأهمية أداء الواجبات البيتية

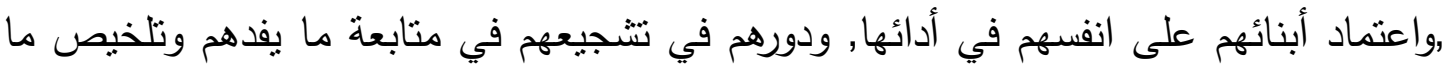
يسمعون من احاديث أو برامج.

• ان لا يلزم المعلم نفسه بوقت محدد وثابت من الدرس لإعطاء الواجب البيتي, وان الأفضل في

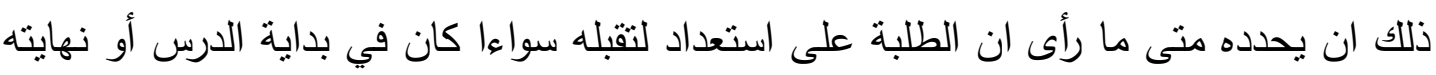

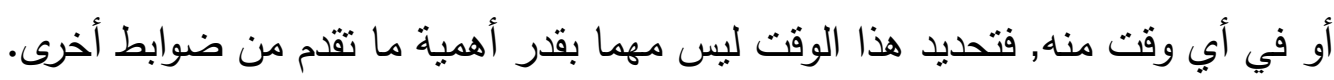

\section{انواع الواجيات البيتية:}

ان التتوع في الواجبات البيتية يعد أمراً ضروريا كي يشوّق الطلبة للارس اكثر ويبعد عنهم الملل من

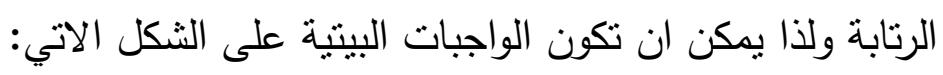
1. إعداد مسبق لموضوع جديد.

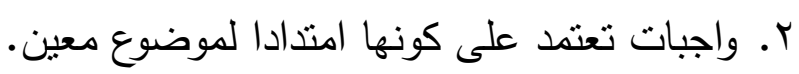
r. ـاجبات تتكون من تمارين تساعد الطلاب على التمكن من مهارات معينة.

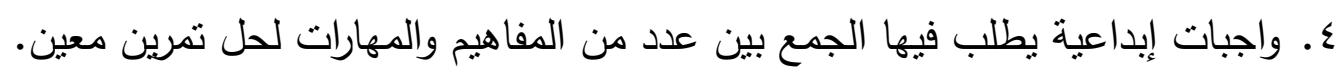

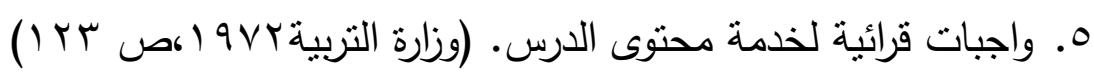
ويمكن أيضاً تصنيف الواجبات البيتية بحسب الغرض منها:

ا. واجبات مراجعة للخبرات التعليمية السابقة وذلك بهدف عدم نسيانها أو استخدامها في دروس جديدة أو تهيئة الطالب لاختبار ما. r. واجبات لتتمية الخبرات التعليمية الجديدة في الدرس الحالي. 
r. واجبات لنتمية الخبرات التعليمية المستقبلية وتعطى كمقدمة لدرس جديد.

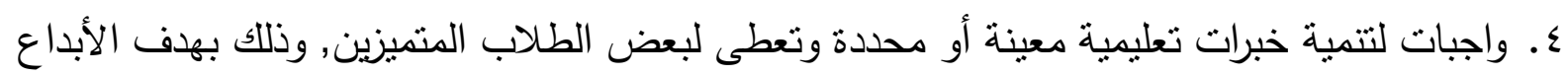

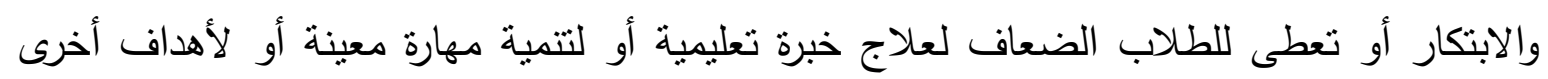

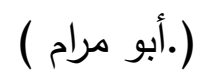

\section{أخطاء المدرسين في الواجبات البيتية:}

على الرغم مما تقدم ذكره في ان للواجبات البيتية إيجابيات ووظائف متعددة لكن في الوقت نفسه قد

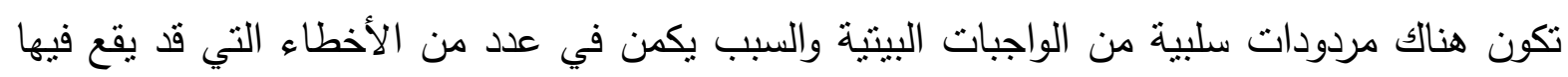
المدرس والتي يمكن تقسيمها إلى مجالين: • • • الاول:مجال تحديد الواجبات البيتية. • الثاني:مجال تقويم(تصحيح) هذه الواجبات.

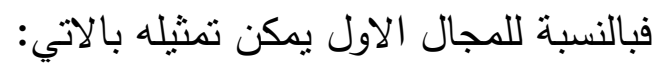
1. قد يكون الددرس قليل الخبرة بهذا الجانب ,أو غير مقتتع به. r. قد يركز اهتمامه على جانب ويترك الجوانب الأخرى فمثلا يكلف طلابه بقراءة الصفحات ويبتعد لهاتيل

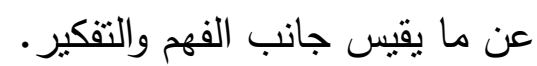
r. لا يكلف نفسه في إيضاح السبل والكيفية التي يتبعها الطالب في تحضير الواجب البيتي. ـ. عدم تخصيص وقت كافٍ لأدائه. ه. قد يتخذ من الواجب البيتي وسيلة للعقاب في الوقت الذي هو وسيلة للتعلم والمنافسة والأبداع أما بالنسبة للمجال الثاني فهناك بعض الأخطاء يقع فيها بعض المدرسين في تقويم الواجبات 
ا ـ قلة متابعة المدرسين للواجبات البيتية, وعدم تصحيحها.

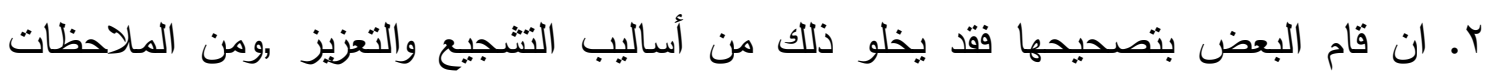
التوجيهية والإرشادية. r. اغلييه المدرسين يقتصرون في تصحيحهم على أساليب الانتقاد لما عند الطلبة من تقصير في إنجازها بدلا من توجيههم وتعزيز الجوانب الإيجابية لديهم.

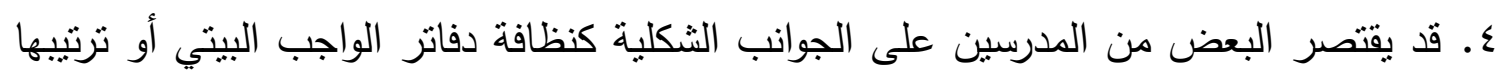
ولم يدققوا ما فيها من أخطاء لغوية أو إملائية أو نحوية وبذلك يصبح هذا الونب لواجب سبيلا للخطأ بأنواعه. 0. لم يخصص بعض المدرسين درجة للواجب البيتي مما يقلل اهتمام الطالب به. وقد اقترح( كوبر)عددا من المقترحات أو التوجيهات للتقليل من شعور الطلاب بثقل الواجبات البيتية منها: ت تسيق السياسات المتعلقة بها وبخاصة بين المدرسة والأسرة.

$$
\text { • تحديد مبرراتها بوضوح. }
$$

$$
\text { • • ربطها بمستوى نمو الطفل ومدى دعم الأسرة له ولها. }
$$

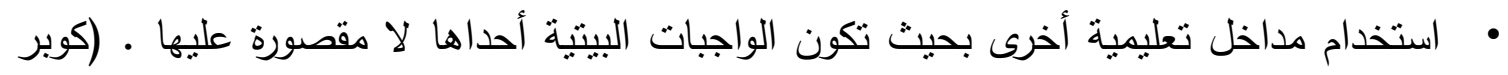

$$
\text { (101-) } \leqslant 10 \text { (199. }
$$

\section{ثانيا:دراسات سابقة}

1- (دراسة شبيب •99 1): اثر التعيينات البيتية التحضيرية والتدريبية في تحصيل طلبة الصف

$$
\text { التاسع في قواعد اللغة العربية }
$$




$$
\text { أجريت هذه الدراسة في الأردن وكانت تهدف إلى: }
$$

1- معرفة الفرق بين مستوى تحصيل الطلبة المكلفين بتعيينات بيتية مقارنة بالذين لم يكلفوا بها. r- معرفة مستوى الطلبة المكلفين بتعيينات بيتية مقارنا بالذين كلفوا بتعيينات تدريبية.

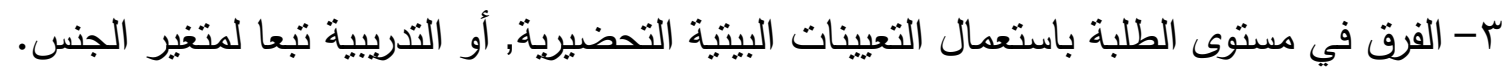
تكونت عينة الدراسة من(مبه )طالبا , وطالبة من الصف التاسع في مدارس وكالة الغوث الدولية في منطقة عمان الجنوبية ,موزعين.

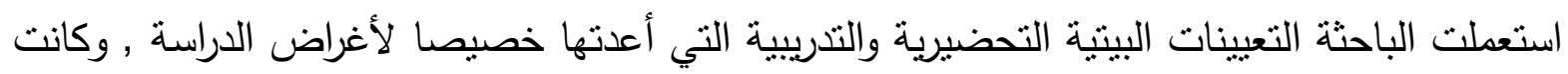

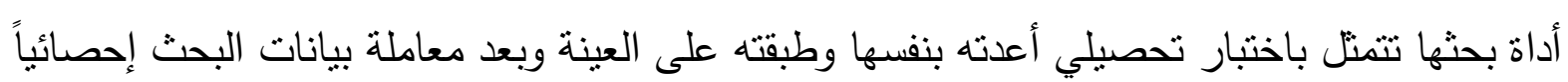
ظهرت الباحثة بالنتائج الأثنة-- (n)

ا - وجود اثر ذي دلالة إحصائية للتعيينات البيتية التحضيرية, والتدرييية في التحصيل الدراسي لكل من الذكور والإناث. r- عدم وجود فرق ذي دلالة إحصائية بين تحصيل الطلاب , والطالبات باستعمال التعيينات البيتية التحضيرية أو التذريبية. ץ-(دراسة رشيد (99 (1)):(تجاهات المعلمين وطلبة الصفوف الثلاثة(السابع والثامن والتاسع )نحو الواجبات البيتية في مادة اللفة العربية والمشكلات التي تعوق أدائها أجريت هذه الدراسة في الأردن وكان هدفا الدراسة: 1 - معرفة اتجاهات المعلمين والطلبة نحو الواجبات البيتية. r- تعرف المشكلات التي تعوق أداء هذه الواجبات. 
تمثلت عينة الدراسة بالمعلمين الذين يُدرسون مادة اللغة العربية للصفوف الثلاثنة( السابع والثامن والتاسع) من المرحلة الأساسية في مدارس اربد الحكومية البالغ عددهم( (1) (1)معلما ومعلمة , وشملت عينة الدراسة (דrT ) طالبا وطالبة من طلبة الصفوف الثثلاثة( السابع والثامن والتاسع )من المرحلة

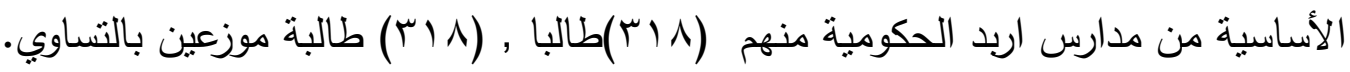

أما أداة البحث فقد تمثلت بمقياس اعده الباحث بنفسه. وعامل بياناته بعدد من الوسائل الإحصائية منها تحليل التباين والاختبار التائي.وظهر بعدد من النتائج منها: ا - إيجابية اتجاهات المعلمين , وطلبة الصفوف الثلاثثة(السابع والثامن والتاسع)من المرحلة الأساسية في مادة اللغة العربية. r- لا تختلف الاتجاهات نحو الواجبات البيتية في مادة اللغة العربية تبعا لمتغير الجنس. ז- لا يوجد اختلاف بين المعلمين, والطلبة في اتجاهاتهم نحو الواجبات البينية.

من المشكلات التي تعوق أداء الواجبات البيتية في مادة اللغة العربية أنها لم تؤدَ بشكل مقبول لعدم تخصيص درجات لها ,وعدم تصحيحها أو تصويب ما فيها من أخطاء كي يتداركها الطلبة وعدم منابعة أولياء الأمور لأبنائهم وتعاونهم مع المدرسة في ذلك مما يدفع الأبناء لإهمالها

r-(دراسة عاشور ؟99 1) :الواجبات المنزلية في مدارسنا, واقعها ,ايجابياتها وسلبياتها أجربت هذه الدراسة في دولة قطر , وهدفت تعرف واقع الواجبات المنزلية في مدارس دولة قطر , ايجابياتها وسلبياتها.

كانت عينة البحث تتمثل ب(س9)تلميذا وتلميذة من الابتدائية , و(99)طالبا وطالبة من المرحلة المتوسطة و) (ov) طالبا وطالبة من الإعدادية. أما أداة البحث فقد تمثلت باستبانة اعدها الباحث بنفسه وعرضها على عدد من الخبراء لتأكيد صدقها وبعد معاملة البيانات إحصائياً بعدد من النتائج منها: 
1- ان اكثر الطلاب التزاما بمراجعة الدروس قبل أداء الواجبات البيتية هم تلامذة المرحلة الابتدائية r- نسبة إهمال الطالب لواجباته قليلة جدا تتراوح بين(r \%)و ( V \%) في المراحل جميعا. r- حرص الطالبات على نحو عام وفي المراحل جميعا على تأدية الواجبات مقارنة بالطلاب. ع- (دراسة علي ع . . ץ):اتجاهات مدرسي اللغة العربية في المرحلة الإعدادية وطلبتها نحو الواجبات البيتية ومشكلاتها في مادة قواعد اللغة العربية

$$
\text { أجريت الدراسة في بغداد وكانت تهدف إلى -: }
$$

• تعرف اتجاهات مدرسي اللغة العربية في المرحلة الإعدادية نحو الواجبات البيتية في قواعد اللغة العربية

• تعرف اتجاهات طلبة المرحلة الإعدادية نحو الواجبات البيتية. • تعرف المشكلات التي تعترض أداء الواجبات البيتية في مادة قواعد اللغة العربية. تكونت عينة الدراسة من طلبة الصف الرابع أعدادي والبالغ عددهم ( . . 7) طالب وطالبة ومن

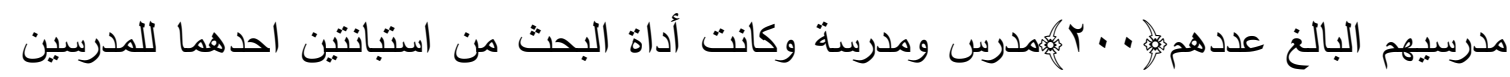
والأخرى للطلبة وقد عامل الباحث البيانات بعدد من الوسائل الإحصائية منها الوسط المرجح والوزن المئوي وظهر عدد من النتائج منها: قلة الحصص المخصصة لقواعد اللغة العربية والتي تجعل المدرس غير قادر على متابعة الواجبات البيتية

• ل الظهر الدورات التدربيية المنعقدة اهتماما بالواجبات البيتية. ( اعتماد غالبية الطلبة الحلول الجاهزة. إهمال الطلبة الواجبات البيتية.

\section{rr.}


موازنة بين الاراسات السابقة وهذه الدراسة- :

لا بد من هذه الموازنة لبيان مدى اتفاق الدراسات السابقة التي ذكرت ,واختلافها وعلاقتها بهذه

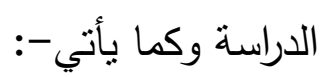

تتوعت الدراسات السابقة في أماكن أجرائها, فقد أجريت كل من دراسة شبيب . 199 , وودراسة

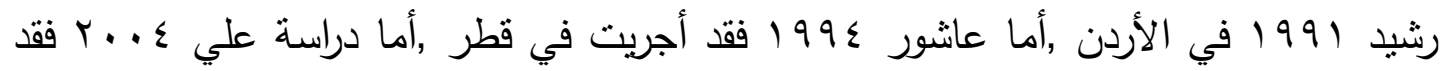
أجريت في العراق وبذلك تتفق مع هذه الدراسة اذا أجريت في العراق أيضاً.

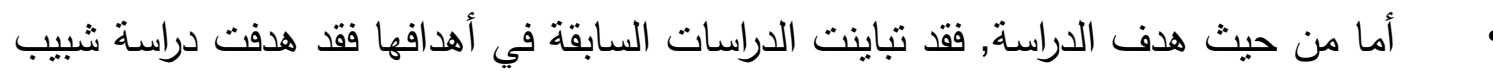

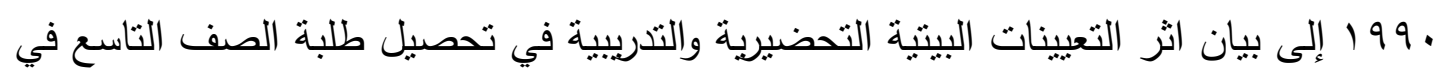

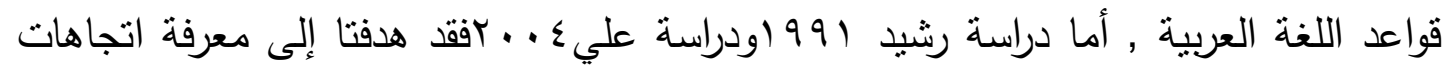

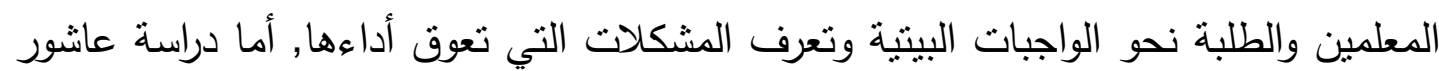

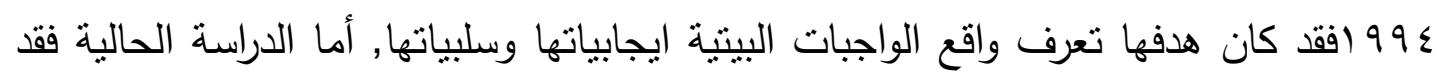

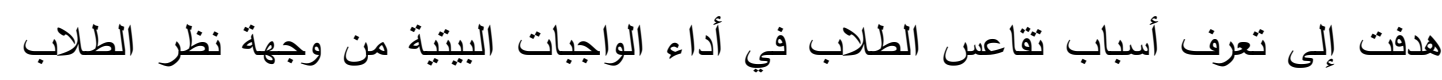
انفسهم ومدرسيهم وبذلك اختلفت في أهدافها عن الدراسات السابقة التي ذكرت.

• أما منهج الدراسة فقد اعتمدت دراسة شبيب .199 المنهج التجريبي في إجراءاتها, أما

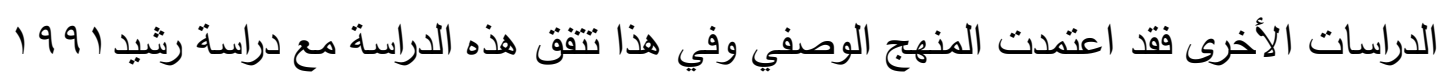

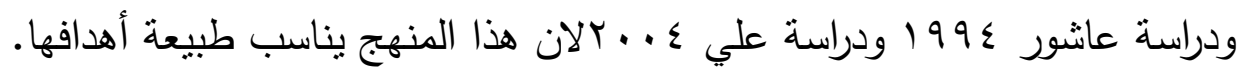

اختلفت حجوم العينات في الدراسات السابقة فقد كانت عينة دراسة شبيب(0ro)طالبا وطالبة

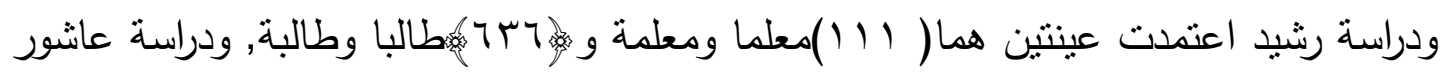

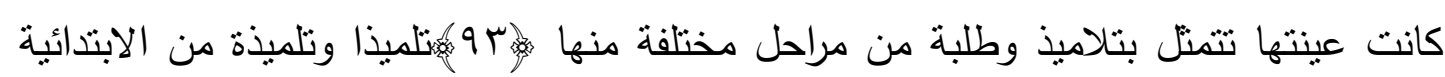

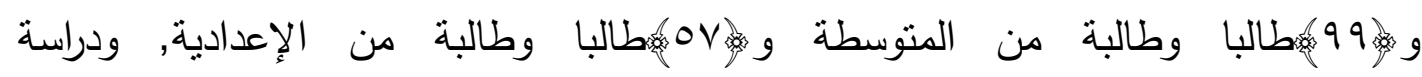

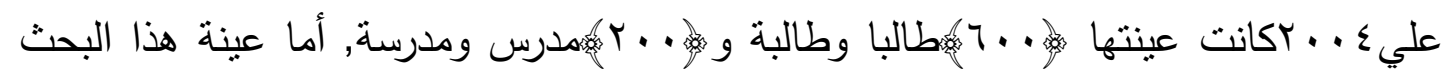




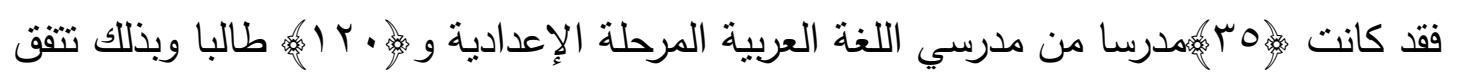
مع ما ذكر من دراسات ماعدا دراسة شبيب .99 الانها اعتمدت عينة من الطلبة فقط.

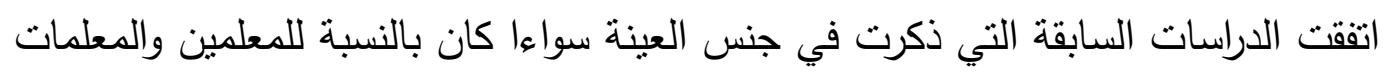

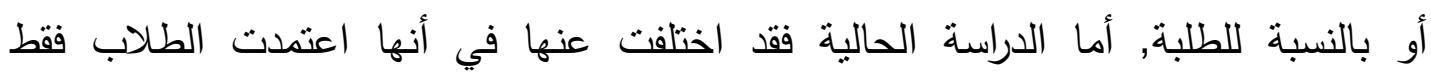

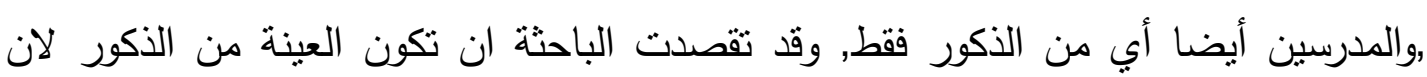

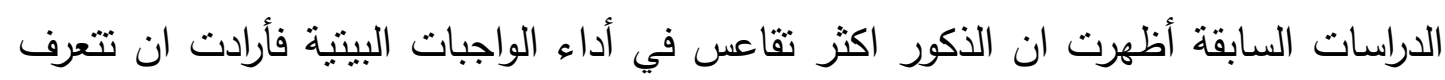
على أسبابها إسهاماً منها بالوقوف عليها واقتراح ما تراه مناسب لعلاجها خدمة للغة الغة العربية. • تباينت المرحلة الدراسية في الدراسات السابقة ففي دراسة شبيب تمثل في الصف التاسع أما

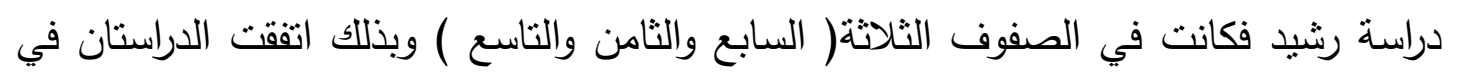

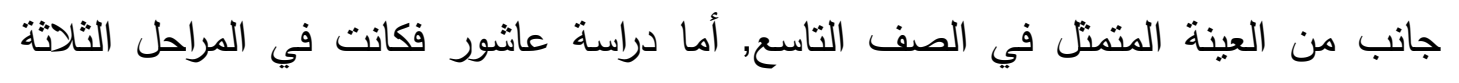

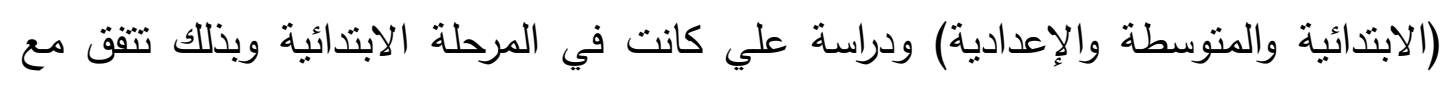
البحث الحالي مما يمكن للباحثة ان تعدها مكملة لها.

نتائج الدراسات: اختلفت الدراسات السابقة في نتائجها لاختلاف أهدافها, لكنها اتفقت جميعها

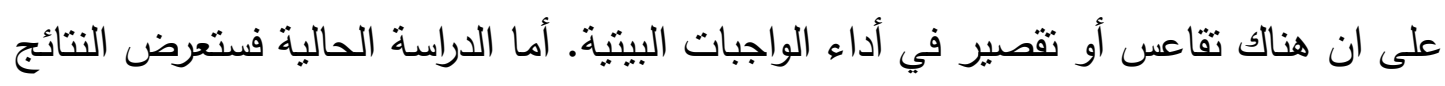
في الفصل الرابع ان شاء الله.

وقد أفادت الباحثة من الدراسات السابقة كثيرا سواء أكان في جوانبها النظرية او منهاجيتها وإجراءاتها أو وسائلها الإحصائية . 


\section{الفصل الثالث}

منهجية البحث وإجراءاته

\section{أولاً:مجتمع البحث-:}

يتكون مجتمع البحث من مدرسي اللغة العربية في المرحلة الإعدادية لمدارس البنين في مديرية

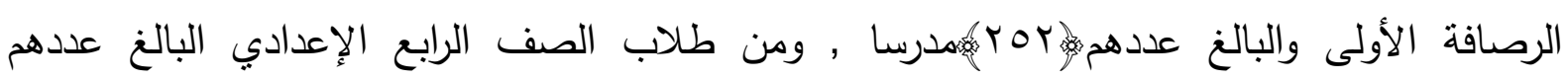

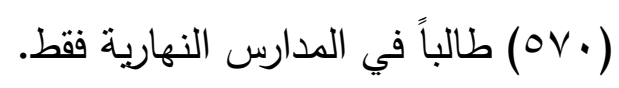

\section{ثنانيا:عينة البحث -:}

لقد اختيرت عينة البحث الحالي بالطريقة العشوائية وكانت من الددرسين والطلاب اذ تم اختيار

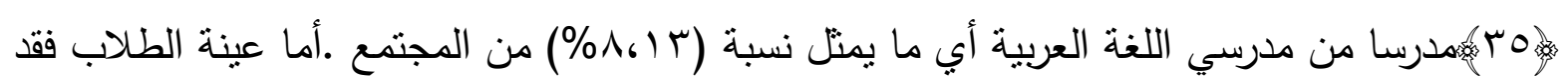

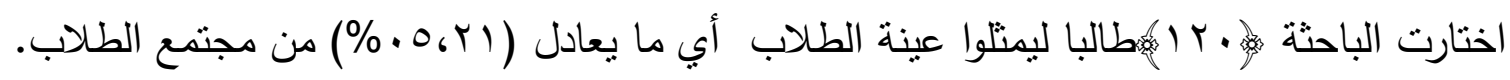
ثالثا:أداة البحث-: تتمنل أداة البحث باستبانة تتكون من مجالين يضم المجال الاول الأسباب المتعلقة بالمدرسين

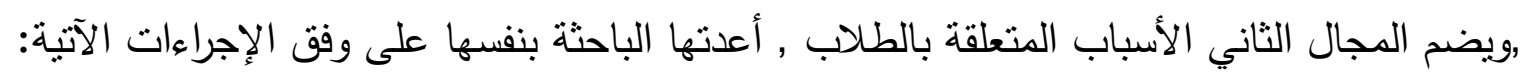

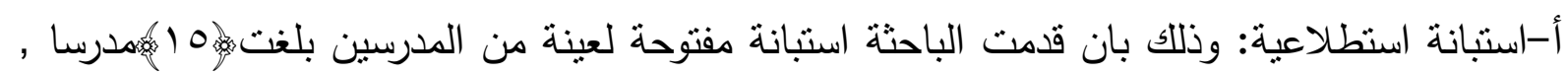

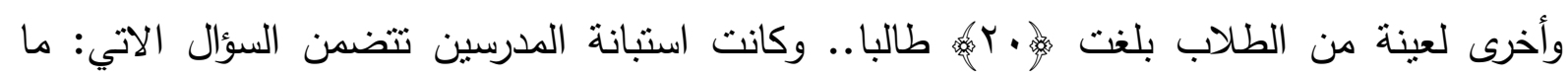

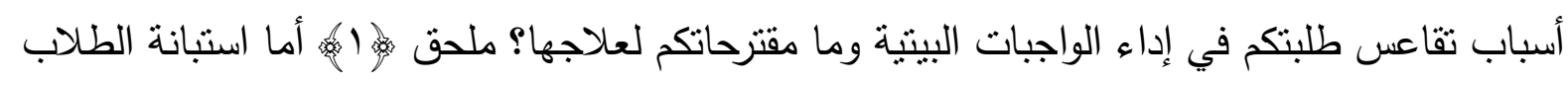
فكانت تتضمن السؤال:

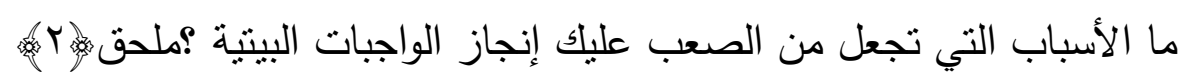


ب-الاطلاع على عدد من الدراسات السابقة والاستفادة من بعض أفكارها و ما ورد في أدواتها من فقرات

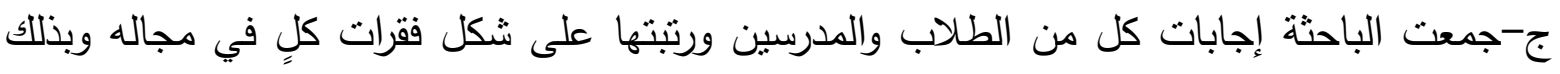

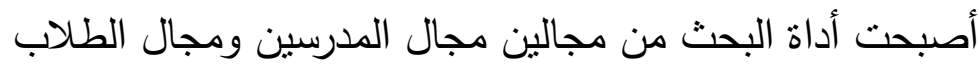

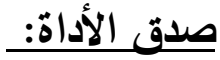

يشير اييل (1972. Ebel) إلى ان افضل وسيلة لاستخراج صدق الأداة هي قيام عدد من الخبراء

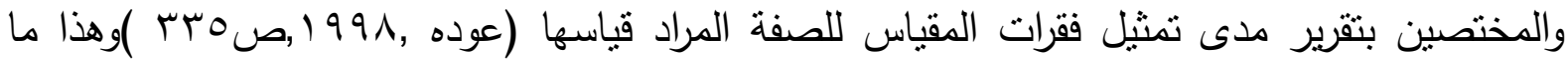

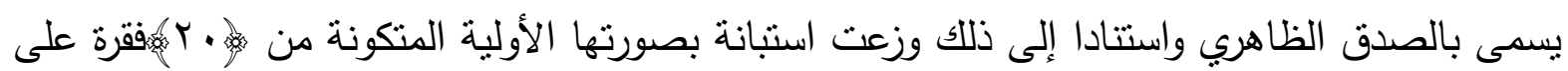

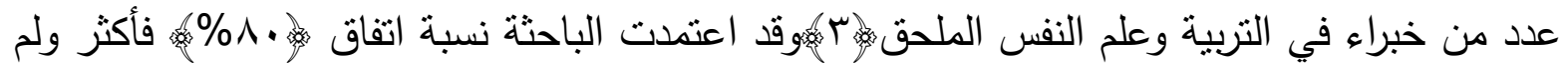
تحذف أية فقرة.

الثبات:

هو الاتساق في إداء الأفراد على وفق الظروف نفسها اذا أعبد تطبيقه على الأفراد انفسهم (سمارة وآخرون 9 19 ,صع (1) (1) وان الهدف من حساب الثبات هو لتقدير أخطاء القياس واقتراح طرائق للتقليل

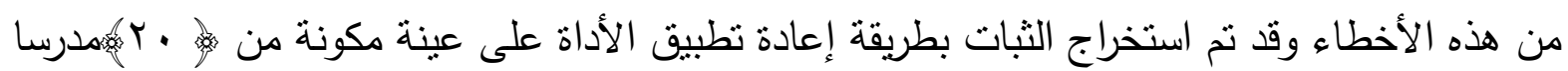

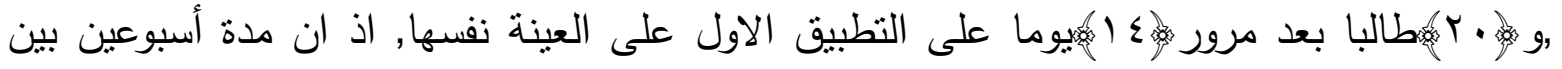

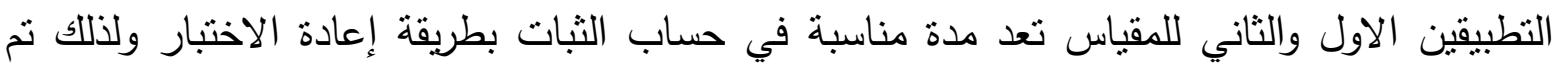

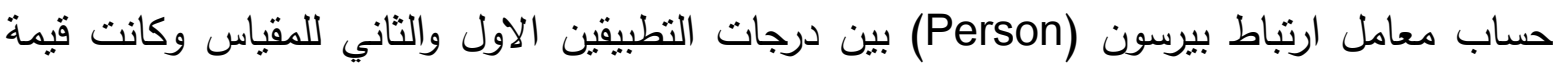

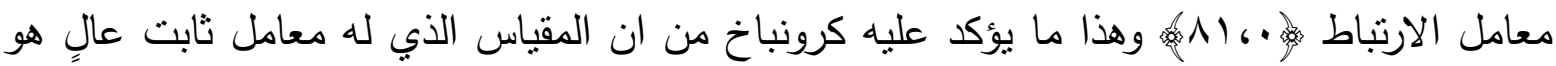

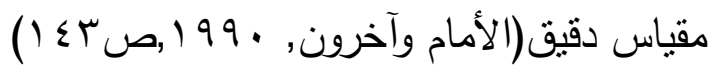


وقد وضع أمام كل فقرة ثلاثة بدائل, هي(أوافق بثدة ,أوافق لحٍٍ ما , لا أوافق) وأعطيت بدائل الإجابة

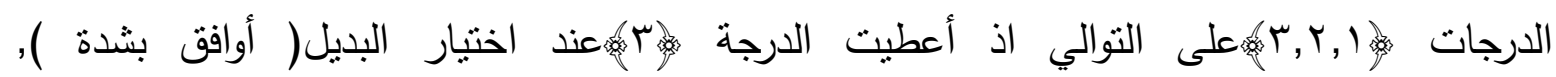

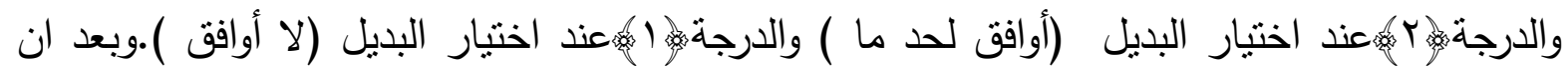

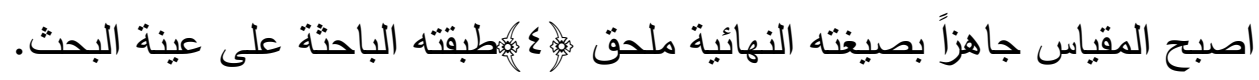

\section{الوسائل الإحصائية:}

لمعالجة بيانات البحث الحالي, فقد استعملت الباحثة الوسائل الإحصائية الأتية :

$$
\begin{aligned}
& \text { 1-معامل ارتباط بيرسون (ر )لحساب ثبات الأداة }
\end{aligned}
$$

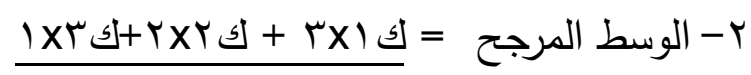

$$
\begin{aligned}
& \text { مج ك }
\end{aligned}
$$

الوسط المرجح

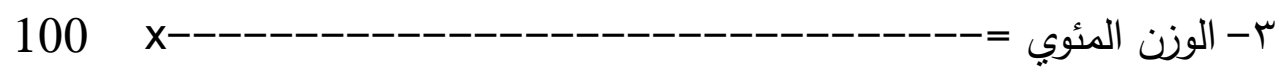

الدرجة القصوى

والدرجة القصوى في هذا المقياس هي هوبر

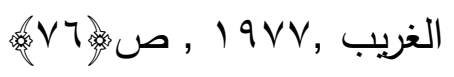




\section{الفصل الزرابع}

\section{عرض النتائج وتفسيرها}

بعد ان طبقت الباحثة أداة البحث ظهر لديها عدد من البيانات فقامت باستخراج الوسط المرجح والوزن المئوي لكل فقرة من فقرات الأداة) أي لكل سبب من أسباب التقاعس (وفي ضوء لداء هذه النتائج

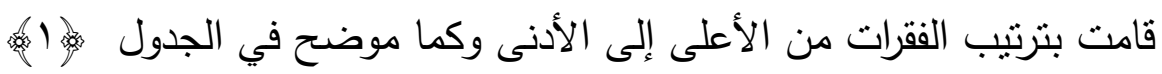

\section{جدول}

يبين فقرات الأداة مرتبة من الأعلى إلى الأدنى على وفق الوسط المرجح والوزن المئوي لها.

\begin{tabular}{|c|c|c|c|c|}
\hline & & المجال الاول/الأسباب المتعلقة بالمدرسين & & \\
\hline الوزن المئوي & المرجط & 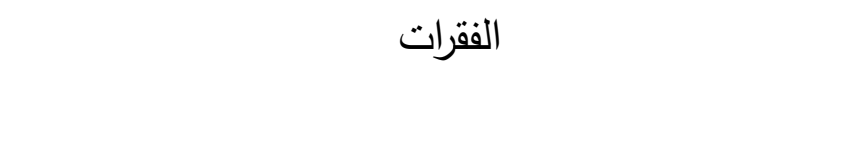 & 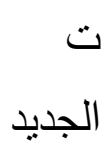 & سابق \\
\hline $94 \%$ & 2,82 & طن الدراسة الموبايل والأنترنيت مما يصرف اهتمام الطالب & 1 & 2 \\
\hline $85,6 \%$ & 2,57 & عن التمضاد الدروس الخصوصية والعلاقات الثخصية بدلا & 2 & 4 \\
\hline $84,6 \%$ & 2,54 & ضعف ميل الطالب للغة العربية أو عدم رغبته فيها & 3 & 1 \\
\hline $80 \%$ & 2,4 & أ-ضعف المستوى العلمي للطالب او عدم متابعة أسرته & 4 & 6 \\
\hline $80 \%$ & 2,4 & ب-(أمبة الأب وألام) ولي امر الطالب & & 8 \\
\hline $77 \%$ & 2,31 & كثرة الألعاب الرياضية وانشغالهم بمتابعتها أو المشاركة & 5 & 9 \\
\hline
\end{tabular}




\begin{tabular}{|c|c|c|c|c|}
\hline & & فيها & & \\
\hline $71,3 \%$ & 2,14 & عدم ادراك الطالب ضرورة الاهتمام بمستقبله الدراسي & 6 & 3 \\
\hline $65,3 \%$ & 1,97 & الوابتعاد الددرسة عن أسلوب العقاب عند التقصير في أداء & 7 & 5 \\
\hline $63,6 \%$ & 1,91 & الثعور بالمسؤولية العيش المرفهة لبعض الطلبة يبعدهم عن & 8 & 7 \\
\hline & & المجال الثاني/الأسباب المتعلقة بالطلاب & & \\
\hline $95 \%$ & 2,85 & شعدر الطالب بعدم أهية الواجب البيتي لعدم تخصيص & 1 & 4 \\
\hline $91,3 \%$ & 2,74 & روتين الواجب البيتي مما يبعث الملل في النفس & 2 & 1 \\
\hline $90,3 \%$ & 2,71 & أ-طول الواجب البيتي من حيث الكم & 3 & 7 \\
\hline $90,3 \%$ & 2,71 & ب-كثرة الواجبات الييتية فقد تكون بعدد المواد الدراسية & & 9 \\
\hline $82,6 \%$ & 2,48 & عدم توضيح المعلم للموضوع بصورة تحقق الفهم للطالب & 4 & 5 \\
\hline $80,66 \%$ & 2,42 & بوارتباط بعض الطلبة بعمل بعد الدوام او انشغالهم & 5 & 2 \\
\hline $80 \%$ & 2,4 & عدم متابعة الددرس المستمرة للواجبات البيتية & 6 & 6 \\
\hline $79 \%$ & 2,37 & لسرعة فهم الطالب التعليمات الخاصة بالواجب البيتي & 7 & 3 \\
\hline $75 \%$ & 2,25 & عدم أفهام المعلم الطالب ان الواجب البيتي جزء من & 8 & 8 \\
\hline $57 \%$ & 1,71 & عدم توافر الجو المناسب للدراسة في البيت لضيقه وكثرة & 9 & 11 \\
\hline
\end{tabular}




\begin{tabular}{|r|r|r|r|r|}
\hline & & أفراد العائلة & & \\
\hline $57 \%$ & 1,71 & عدمديد المعلم الواجب البيتي بصورة دقيقة 10 & 10 \\
\hline
\end{tabular}

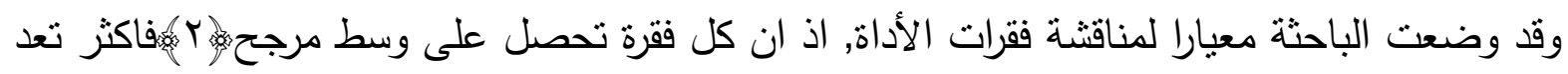

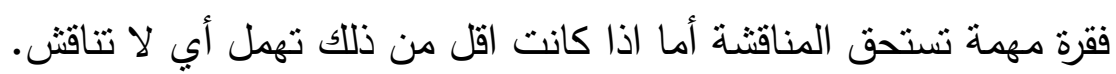

\section{تفسير نتائج المجال الاول-:}

1-حصلت الفقرة( ظهور الموبايل والأنترنيت مما يصرف اهتمام الطالب عن الدراسة) على المرتبة

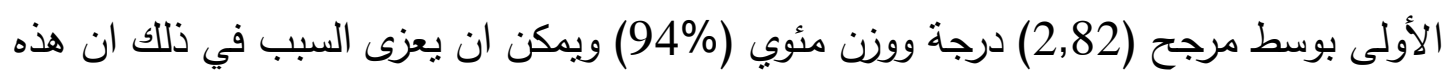

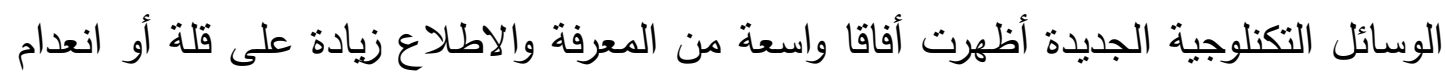

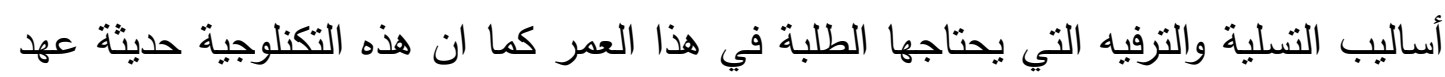
في العراق لذلك انصرف اليها الطلبة وانشغلوا بها.

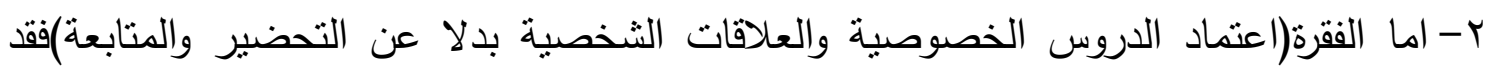

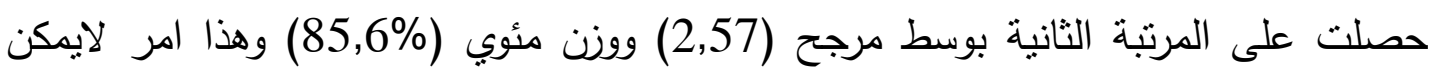

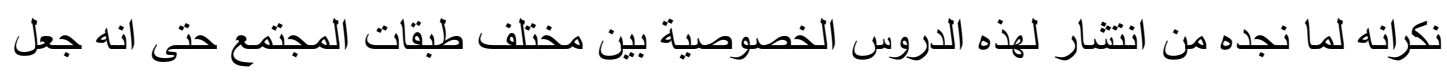

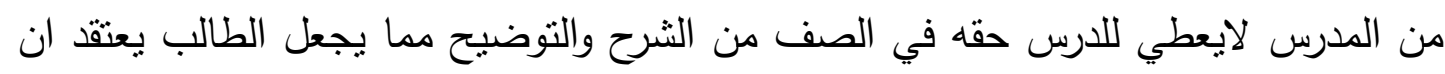

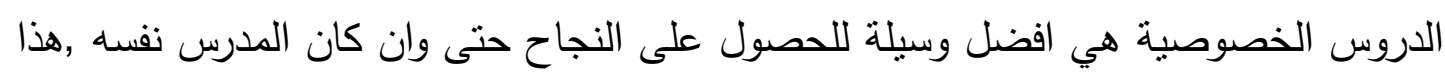

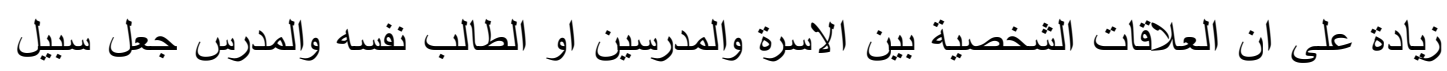

$$
\text { النجاح سهلا لايحتاج الى دراسة ومثابرة. }
$$

ץ- اما الفقرة(ضعف ميل الطالب للغة العربية اوعدم رغنبته فيها) فقد حصلت على وسط مرجح (2,54)ووزن مئوي (84,6\%)محتلة بذلك المرتبة الثالثة.وهذا مانشعرت به الباحثة في اثثاء 
تدريسها للغة العربية في المدارس الثانوية ولسنوات عديدة ان الطلبة ينفرون من درس اللغة العربية لصعوبتها ولتعدد فروعها او رتابة الطريقة التي تدرس بها او ما الى ذلك من اسباب. ع- اما الفقرتان(أ-ضعف المستوى العلمي للطالب او عدم منابعة اسرته له)و (ب-امية الاب والام ولي امر الطالب) فقد احتلا مرتبة متساوية بحصولها على وسط مرجح $(2,4)$ ووزن مئوي (80\%)وهذا مايؤكد الدور الذي تلعبه الاسرة في حياة الطالب سواءا بمنابعتها له وحثه على اداء واجباته المدرسية او مشاركة المدرسة في ذللك ,فكلما زادت ثقافة الاب والام كلما اثر ذلك ايجابا في المستوى العلمي لابنائهم وبالعكس. ه- اما الفقرة( كثرة الالعاب الرياضية وانشغالهم بمتابعتها او المشاركة فيها )ققد حصلت على وسط مرجح (2,31) ووزن مئوي (77\%) مما يثير الى دورها في تقاعس الطلاب في اداء واجباتهم المنزلية , اذ ان كثرة الالعاب الرياضية وانتشارها على مساحة واسعة جعل الطلاب ينصرفون اليها فالابناء بطبيعتهم يغلب عليهم الميل الى هذه الالعاب ويعبرون عن ذلك بمشاركتهم فيها او متابعتهم عن طريق التلفاز او حضور الملاعب وما الى ذلك ,كل هذا يأخذ منهم وقتا طويلا وجها ليس بالقليل مما ينعكس ذلك على ادائهم لواجباتهم المدرسية وتحضير دروسهم.

צ- اماالفقرة(عدم ادراك الطالب ضرورة الاهتمام بمستقبله الدراسي) فقد حصلت على وسط مرجح (2,14)ووزن مئوي (71,3\%) محتلة بذلك مرتبة نتير الى ان مستقبل الطالب مرهون بجده ومثابرته وعدم تقاعسه في اداء واجباته الامر الذي لايدركه كثير من ابنائنا الطلبة اذ يرون ان مستقبلهم الدراسي يمكن ان يبنى باستعدادهم للامتحانات النهائية واجتيازها فلا بهتمون بما يتطلبه العام الدراسي من واجبات ومهمات. 


\section{تفسير نتائج المجال الثاني -:}

اما بالنسبة للنتائج المتعلقة بمجال الطالب فيمكن تفسيرها بالثكل الاتي:

1- احتلت الفقرة(شعور الطالب بعدم اهمية الواجب البيتي لعدم تخصيص الددرس درجة له)المرتبة

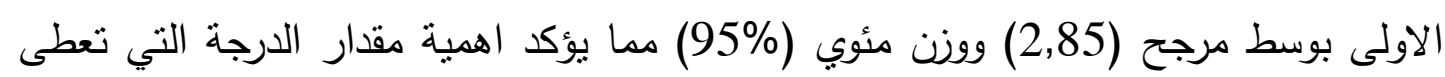

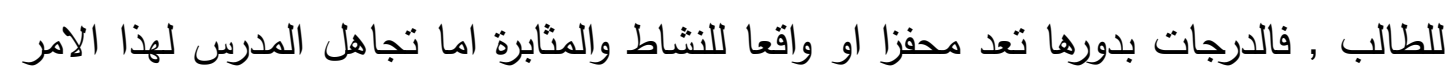

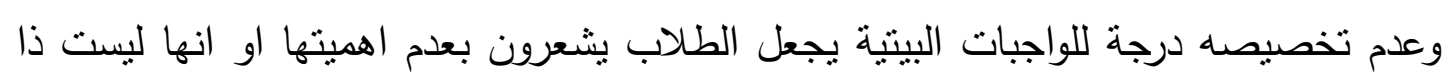
تأثير في نجاحهم. r- اما الفقرة(روتين الواجب البيتي مما يبعث الملل في النفس )فقد حصلت على وسط مرجح

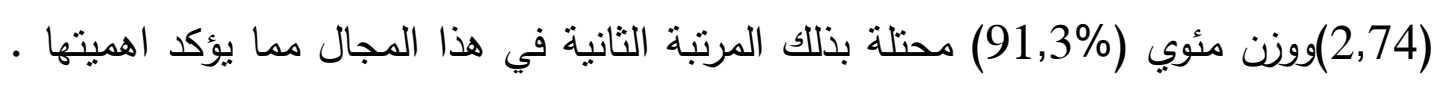

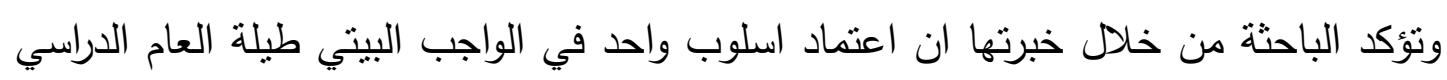

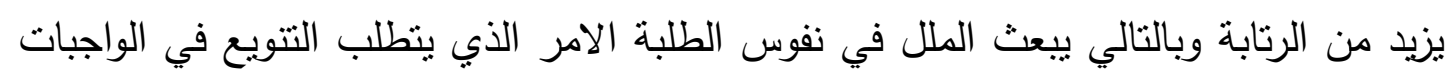

$$
\text { البيتية وجعلها مثيرة اكثر للتفكير. }
$$

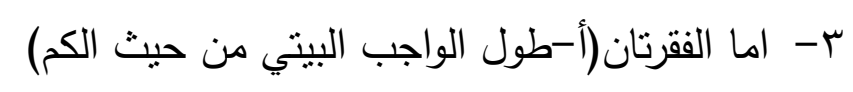

ب-(كثرة الواجبات البيتية فقد نكون بعدد المواد الدراسية)

فقد حصلت كل منهما على وسط مرجح (2,71) ووزن مئوي (90,3\%) مما يثير الى اهميتها وتأثيرها

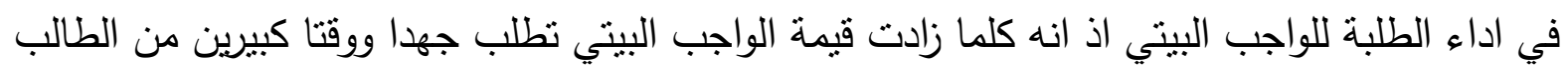

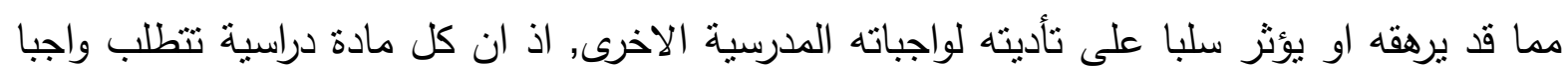

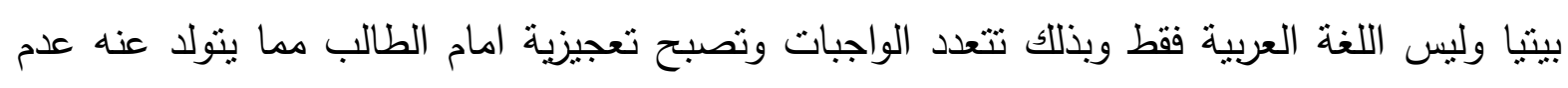
انجازها او التقصير فيها.

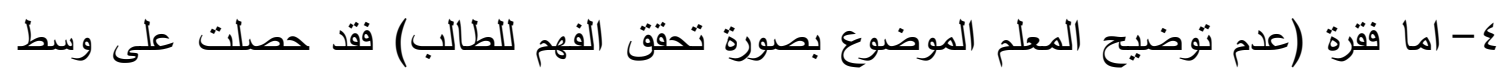

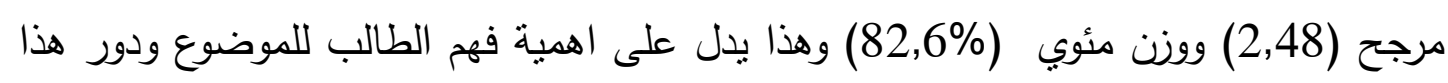


الفهم في تمكن الطالب من انجاز الواجبات البيتية , اذ ان حل التمرينات والاسئلة المتضمنة في

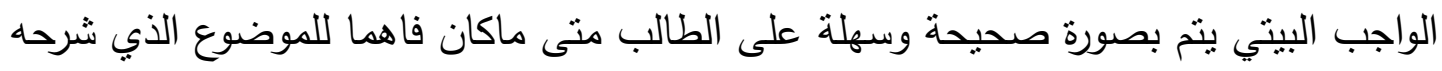
المعلم والعكس صحيح. 0- اما فقرة(ارتباط بعض الطلبة بعمل بعد الدوام او انشغالهم بواجبات اسرية) فقد حصلت على الثى وسط مرجح (2,42) ووزن مئوي (80,6\%) واحتلت بذلك مرتبة نتير الى اهميتها اذ ان كثرة

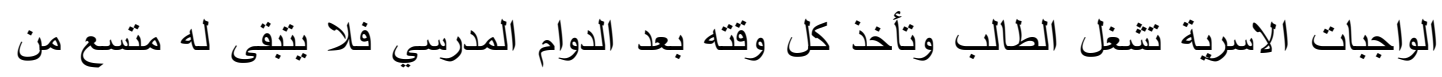
الوقت لانجاز واجباته المدرسية.

1- اما فقرة( عدم مثابعة المدرس المستمرة للواجبات البيتية )فقد حصلت على وسط مرجح $(2,4)$ ووزن مئوي (80\%) محتلة بذلك مرنبة تثير لاهمية متابعة المدرس المستمرة لطلابه في ادائهم

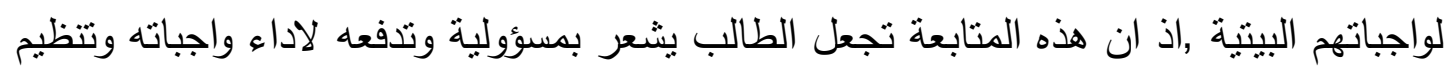
وقته بشكل يسيطر فيه على واجباته ويؤديها بشكل منظم ومخطط له.

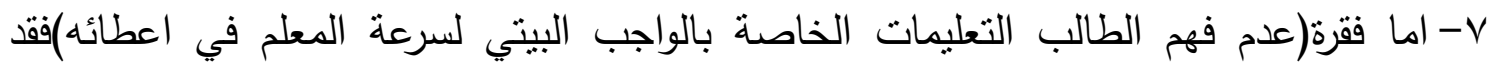
حصلت على وسط مرجح (2,37) ووزن مئوي (79\%) محتلة به مرنبة تنثير الى ان عدم فهم

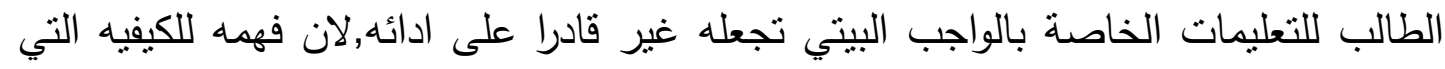

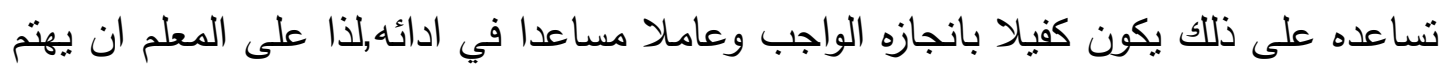
بذلك ويعطي الوقت الكافي لتوضيح هذه التعليمات بعيدا عن السرعة غير المناسبة لطلابه.

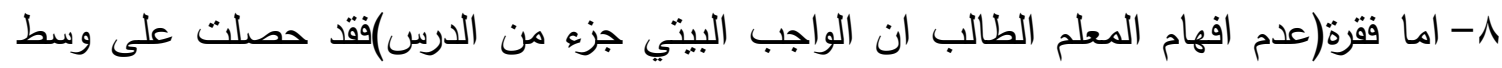

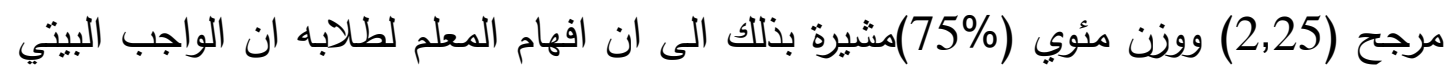

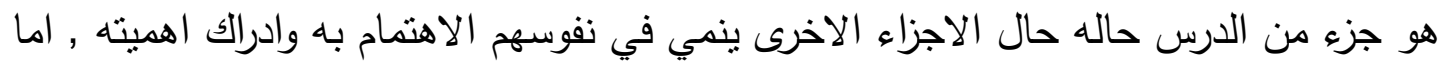
ما عدا ذللك فيبقى الطالب ينظر الى الواجب البيتي على انه ليس ذاه الها اهميه او تاثير فيه. 


\section{مقترحات لتطوير الموقف من الواجبات الييتية-:}

في ضوء النتائج وتفسيرها تقترح الباحثة عدد من المقترحات لنطوير الموقف من الواجبات البيتية وتعزيز دورها في العملية التعليمية واهيتها -وهذا مايمثل الهدف الفرعي الثاني -وهذه المترحات هي:-

مساعدة الطالب في حل مايعترضه من مشكلات او صعوبات في اثثاء ادائه الواجبات البيتية بعد نتخيصها والتعرف عليها.

• التخفيف من كاهل الطالب وذلك بتوزيع الواجبات البيتية على الطلاب بجعله على شكل

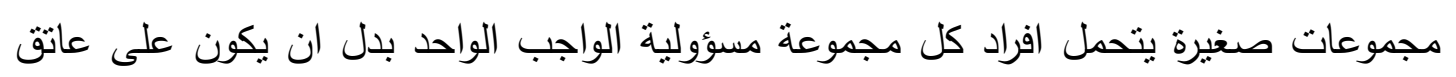
تلميذ واحد بمفرده.

لايتوقف عمل الددرس او دوره بتحديد او تكليف الطالب بالواجب البيتي وانما عليه متابعته بعد ذلك واعطاؤه مايحتاجه من توجيهات.

• التتويع في الواجبات البيتية وتضمينها انشطة علمية مختلفة والعاب مسلية وجوانب فكرية. • تدريب الطالب على كيفية تتظيم وقته اذ يعطي لكل واجب من واجباته حقه من الوقت فلا يركز

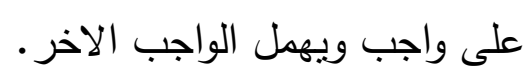

اذا شعر المعلم بصعوبة بعض التمرينات او الانشطة ضمن الواجب البيتي, عليه ان يدرب الطلاب على ذلك باعطائهم امتلة او توضيح كيفية انجازها قبل ان يقوم الطالب بذلك. • اعطاء الطالب الحرية قدر المستطاع في اختيار بعض الواجبات وذلك بان بزيد بعدد التمرينات

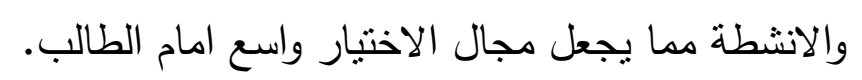

• اعطاء الواجبات البيتية نصيبها من الدرجة الكلية للمادة, وبذلك ياخذها الطالب بنظر الاهتمام

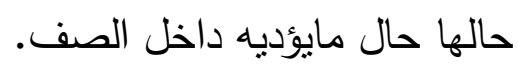




\section{الاستتتاجات:}

في ضوء نتائج البحث تستتتج الباحثة ما يأتي:

1-ان هناك تقاعسا واضحا وكبيرا في اداء الواجبات البيتية.

2-عدم نوافر المتابعة المطلوبة من المدرسين للطلاب في ادائهم للواجبات البيتية مما بلزمهم بأدائها. 3-رتابة الواجبات البيتية من حيث انواعها وكيفية ادائها امر له مردوداته السلبية في اداء الطلاب. 4-للاروس الخصوصية تأثير كبير وسلبي في اداء الطلاب للواجبات البيتية اذ انها تقلل من ادراكهم لهذه الواجبات واهميتها. 5-تخصيص درجة للواجبات البيتية امر ضروري ودافع قوي للطلاب نحو انجازها فأن اهملها المدرس انعكس سلبا على انجازها.

\section{التوصيات:}

في ضوء النتائج التي توصلت اليها الباحثة نوصي بما يأني:

$$
\text { 1- بيان اهية الواجبات البيتية للمدرسين. }
$$

r-تعريف المشرفين بأهمية الواجبات البيتية من اجل توضيحها للمدرسين والمدرسات في الثناء زياراتهم الميدانية لهم.

r- اعتماد المقياس المعد من الباحثة في تعرف اتجاهات مدرسي اللغة العربية ومدرساتها , وطلبة الصف الرابع العام نحو الواجبات البيتية. ع - النوازن في كمية الواجبات المنزلية ومحاولة التتسيق مع المدرسين الاخرين في ذلك. 0- تحديد درجة للواجبات البيتية تكون حافزا للطالب في انجازها. 
צ- محاولة ان يتضمن الواجب العابا مسلية او الغاز او اي انشطة عملية وذلك للترفيه عن الطلبة وابعاد الملل عنهم.

V- محاولة تعرف المعلم على مسببات ميول الطالب السلبية تجاه المادة الدراسية او تجاه المعلم شخصبا وتغير هذه المسببات.

1- على المدرسين المتابعة الدائمة والمستمرة للطلبة في ادائه للواجبات المنزلية , وكتابة

الماحظات التشجيعية والتوجيهية عند تصحيح الدفاتر .

9- اختيار عدد من اسئلة الواجب البيتي في الامتحانات خلال العام الدراسي لأشعار الطلبة بأهميتها وجعلها مرجعا للاختبارات.

المقترحات:

تقترح الباحثة عددا من المقترحات كمشاريع لبحوث قادمة ان شاء الله

1- دراسة مماثلة للدراسة الحالية على مستوى العراق. r- دراسة مماثلة للاراسة الحالية في مرحلة دراسية اخرى. 
ا- آل ياسين ,محمد حسين , وعبد الحميد عبد الكريم .طرق التدربس العامة لدور المعلمين والمعلمات , الصفوف الثانية ,_ط ,مطبعة وزارة المعارف , بغداد ب7 9 ـ.

r- ابو حويج , مروان • المناهج التربوبة المعاصرة - الاساسبات- مشكلات المناهج -تطوير

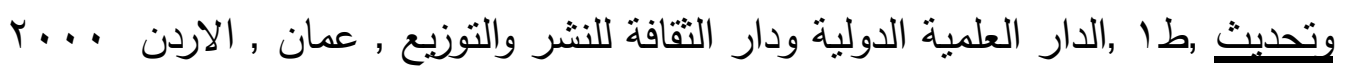

$$
\text { (www.yanabeea.net)، بو مرام }
$$

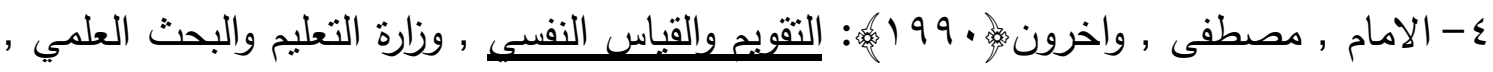
العراق. 0- البجة , عبد الفتاح حسن ,اصيل تدربس العربية بين النظربة والممارسة ,المرحلة الاساسية

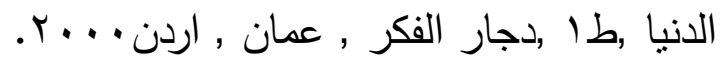

צ- جابر , عبد الحميد جابر ,وعايف حبيب .اساسبات التدربس ,مطبعة العاني ,بغداد, 97 I I .

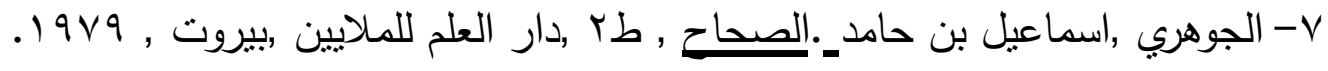
^- الحسون رجاسم احمد • الواجب البيتيـ" النشاط البيتي ."لدروس القراءة , جمهورية العراق , وزارة

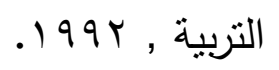

9- الحصري, ساطع_.دروس فيـ اصول التدريس , جا ,الاصول العامة , طV ,مطابع دار

$$
\text { الكثاف ,بيروت , 1901. }
$$

• 1- الرحيم ,احمد حسن, الطرق العامة في التربية, مطبعة الاداب,النجف 970 ا. 197 1ا- رشيد , خليل سامي محمد ـ اتجاهات المعلمين وطلبة الصفوف الثلاثة) السابع والثامن والتاسع (نحو الواجبات البيتية في مادة اللغة العربية والمشكلات التي تعوق اداء هذه الواجبات , مجلة اليرموك ,(المجلد السابع ,جامعة اليرموك ,الاردن , (99 ( ) ,رسالة ماجستير 
rا- الريان , فكري حسن .التدربس اهدافه اسسه واسالبيه ,تقوبح نتائجه وتطبقاته ,عالم الكتب ,

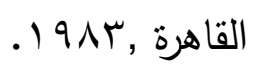

rا- شبيب ,ختام محمد عبد الرحمن. اثر التعبنات البيتبة التحضبرية والتنديبية على تحصيل

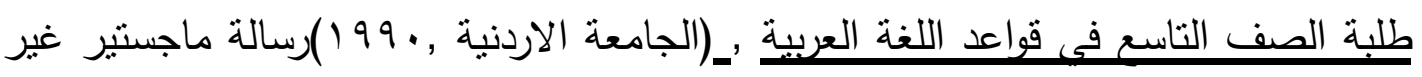

$$
\text { منشورة }
$$

ـ ا- الطاهر , علي جوادـــثربس اللغة العربية في المدارس المتوسطة والثانوبة , مطبعة النعمان

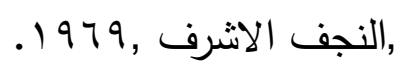

10- عاثور ,فايد حماد. الواجبات المنزلية في مدارسنا- واقعها ايجابياتها , سلبياتها ,مجلة افلقاق

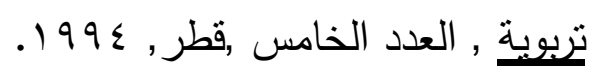

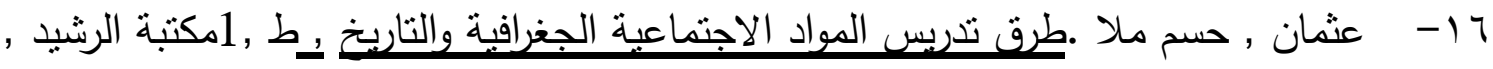

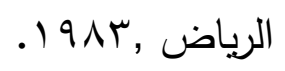

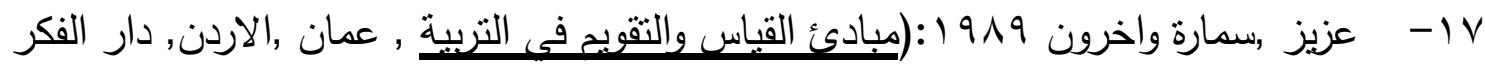

$$
\text { للنشر والتوزيع) }
$$

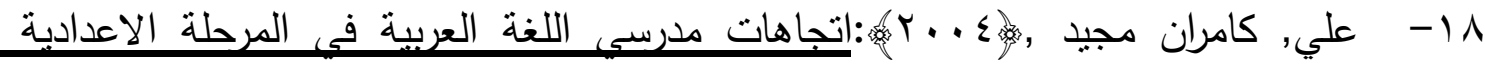

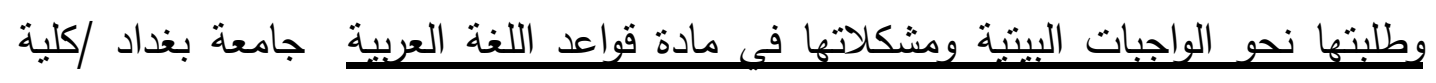

$$
\text { التربية /ابن رشد .رسالة ماجستير. }
$$

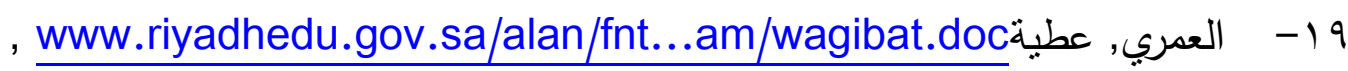

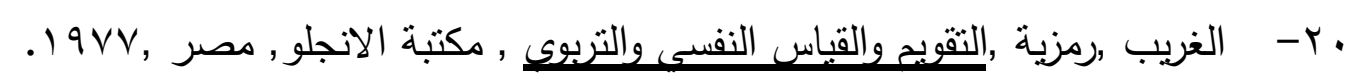

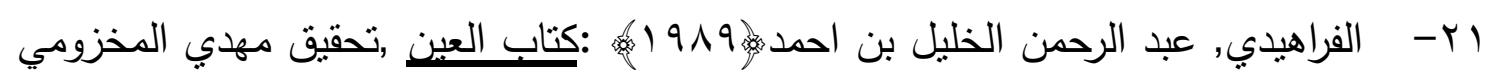

$$
\text { وابراهيم السامرائي , مؤسسة دار الهجرة , طبايران. }
$$

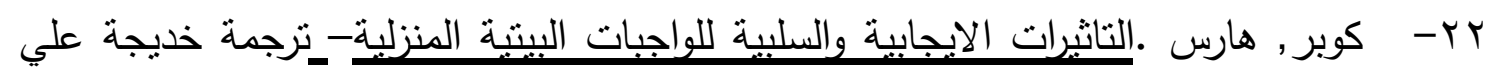

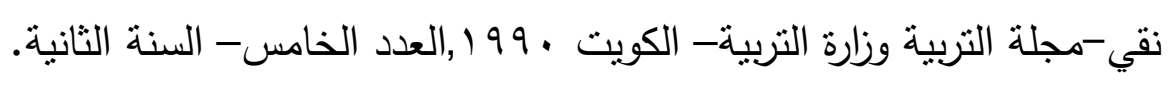


بr- اللقاني, احمد حسين". الواجب المنزلي تشخبص وعلاج , ".التوثيق التربوي , المديرية العمة

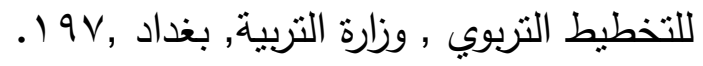
ع

هץ- وزارة التربية, الكتاب السنوى لمدبربة المناهج والكتب ,مطبعة الادارة المحلية , بغداد , $.19 V Y$ 


\section{الملاحق:} \\ بسم الله الرحمن الرحيم

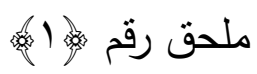 \\ استبانة استطلاعية (للمدرسين)

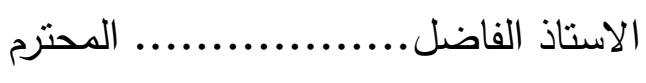 \\ السلام عليكم ورحمة الله وبركاته

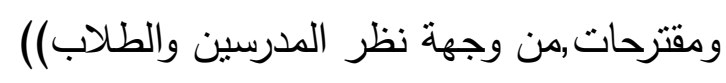

تروم الباحثة القيام بدراستها الموسومة ((تقاعس الطلاب في اداء الواجبات البيتية, اسباب

ونظرا لما تعهده فيكم من العلم والمعرفة, ولما تتوسمه فيكم من استعداد لخدمة اللغة العربية ومشاركة

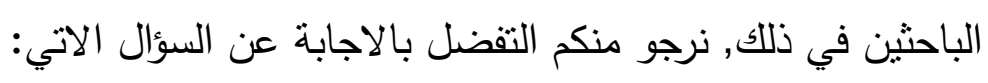

ماسباب تقاعس طلابكم في اداء الواجبات البيتية ؟ومامقترحاتكم لعلاجها ؟ ملاحظة: لاحاجة لذكر الاسم لانه العمل لاغراضالبحث العلمي فقط ولكم الثكر والامتنان

الباحثة 


$$
\text { بسم الله الرحمن الرحيم }
$$

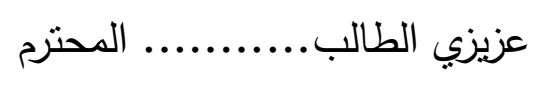$$
\text { السلام عليكم ورحمة الله وبركاته }
$$

تروم الباحثة القيام بدراستها الموسومة(( نقاعس الطلاب في إداء الواجبات البيتية, أسباب

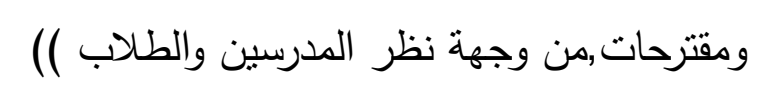

ونظرا لأنك من يكلف بأداء هذه الواجبات نود الباحثة مساعدتها في عملها بالإجابة عن السؤال الاتي: ما الأسباب التي تجعل من الصعب عليك إنجاز الواجبات البيتية ؟ ولك الثكر والامتتان ملاحظة: لا حاجة لذكر الاسم لأنه العمل لأغراض البحث العلمي فقط

الباحثة 


\section{ملحق}

اسماء الخبراء مرنبة وفق الحروف والالقاب العلمية

ط.تدريس اللغة العربية/ التربية ابن

$$
\text { • أ.م.د.رقية عبد الائمة }
$$

ط.تدريس اللغة العربية/ التربية

$$
\text { • أ.م.د.زينب عبد الحسين حمدان }
$$

ط.تدريس الاجتماعيات/ التربية

$$
\text { • أ.م.د.سامي سوسة سلمان }
$$

ط.تدريس اللغة العربية/ التربية

$$
\text { • أ.م.د.سامية كاظم الجبوري }
$$

ط.تدريس اللغة العربية/ التربية

$$
\text { • أ.م.د.علي العبيدي }
$$

ط.تدريس اللغة العربية/ التربية

$$
\text { • أ.م.د.نصيف جاسم }
$$

ط.تدريس اللغة العربية/ معهذ اعداد المعلمات/ الرصافة

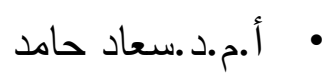

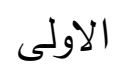


بسم الله الرحمن الرحيم

ملحق رقم

استبانة الخبراء

تحية طيية:

تروم الباحثة القيام بدراسة عنوانها ) اسباب تقاعس الطلاب في اداء الواجبات البيتية,اسباب ومقترحات ,

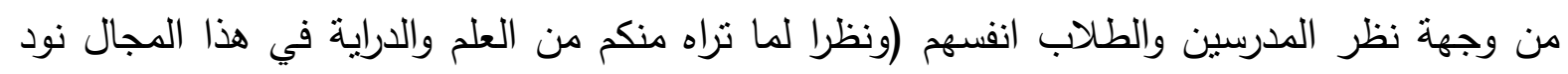
مساعدتكم في بيان مدى صلاحية فقرات الاداة وتعديل ماترونه مناسبا.

$$
\text { ولكم الثكر والامتنان }
$$

الباحثة

\begin{tabular}{|c|c|c|c|c|}
\hline & & & المجال الاول/الاسباب المتعلقة بالمدرسين & \\
\hline \multirow{7}{*}{ تحديل } & & صالحة & 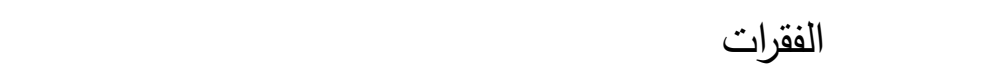 & $ت$ \\
\hline & صالحة & & & \\
\hline & & & & \\
\hline & & & ضعف ميل الطالب للغة العربية اوعدم رغبته فيها & 1 \\
\hline & & & ظهور الموبايل والانترنيت مما يصرف اهتمام الطالب عن الدراسة & 2 \\
\hline & & & عدم ادرالك الطالب ضرورة الاهتمام بمستقبله الدراسي & 3 \\
\hline & & & التحضير والدرتابعة الخصوصية والعلاقات الثخصية بدلا عن & 4 \\
\hline
\end{tabular}




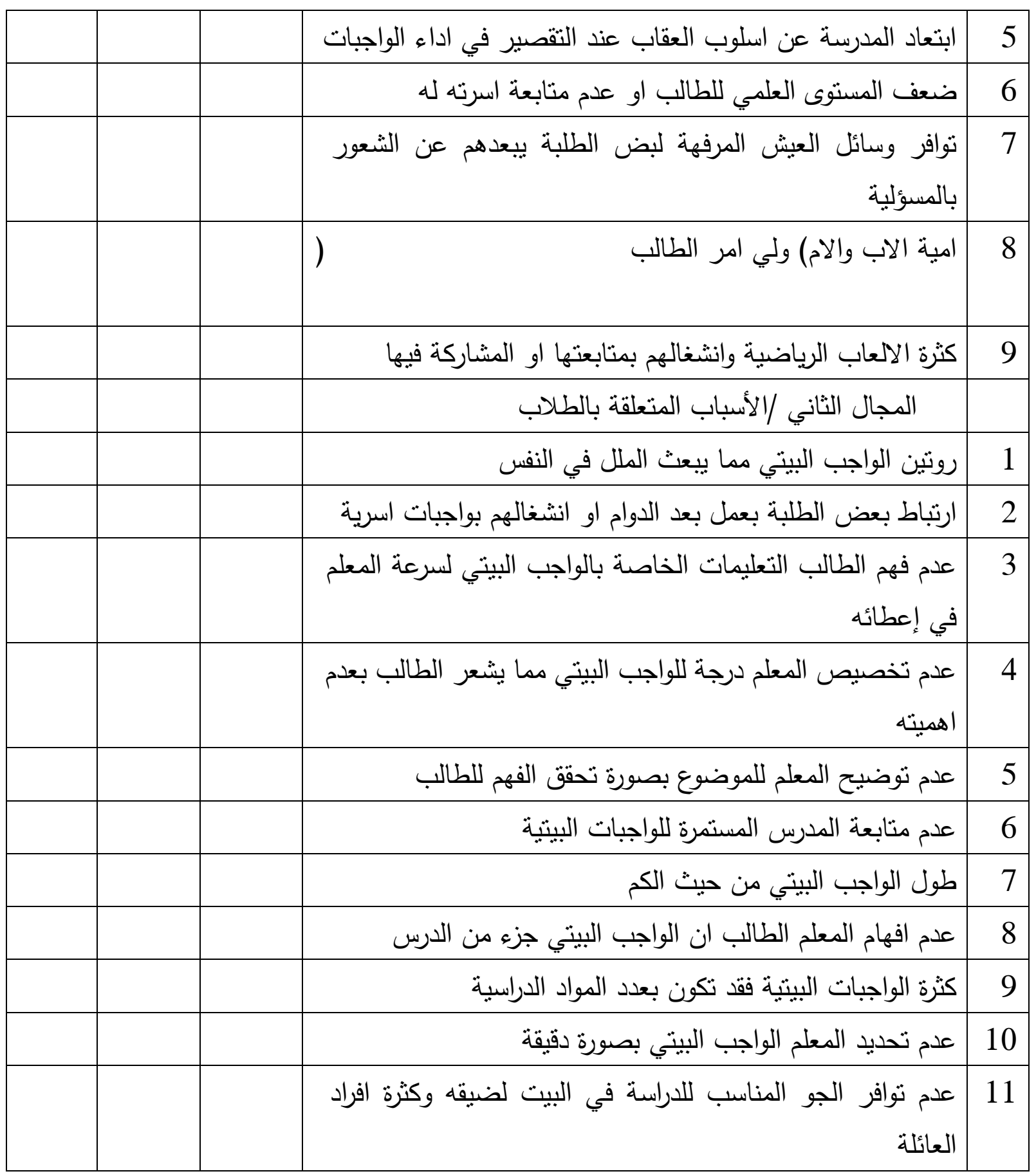




$$
\text { ملحم الله الرحمن الرحيم }
$$

تحية طيية.

تروم الباحثة القيام بدراسة عنوانها ) اسباب تقاعس الطلاب في اداء الواجبات البيتية,اسباب ومقترحات ,

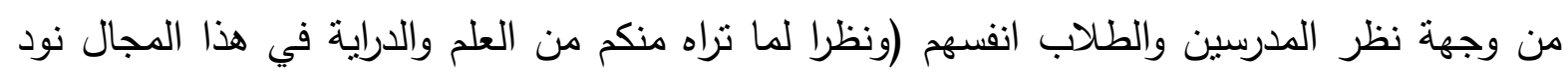

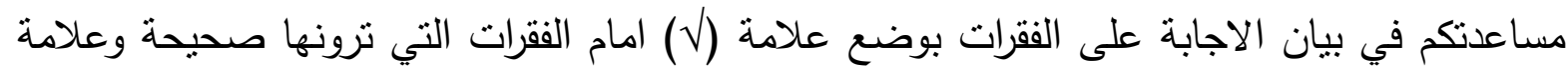
ولكم الثكر والامتتان.

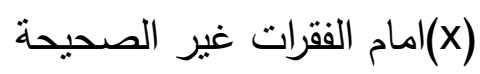

الباحثة 
الاسنبانة النهائية

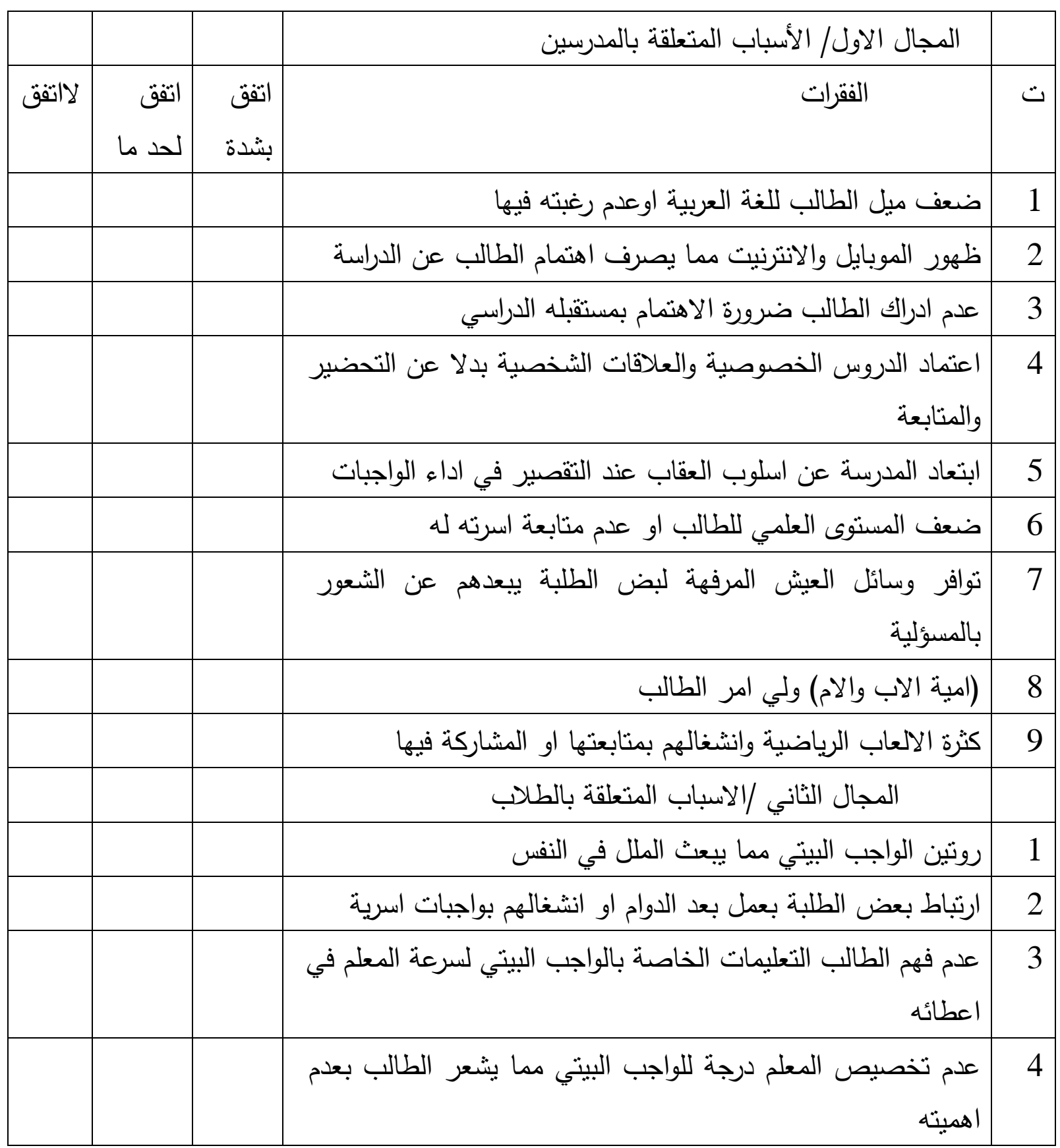




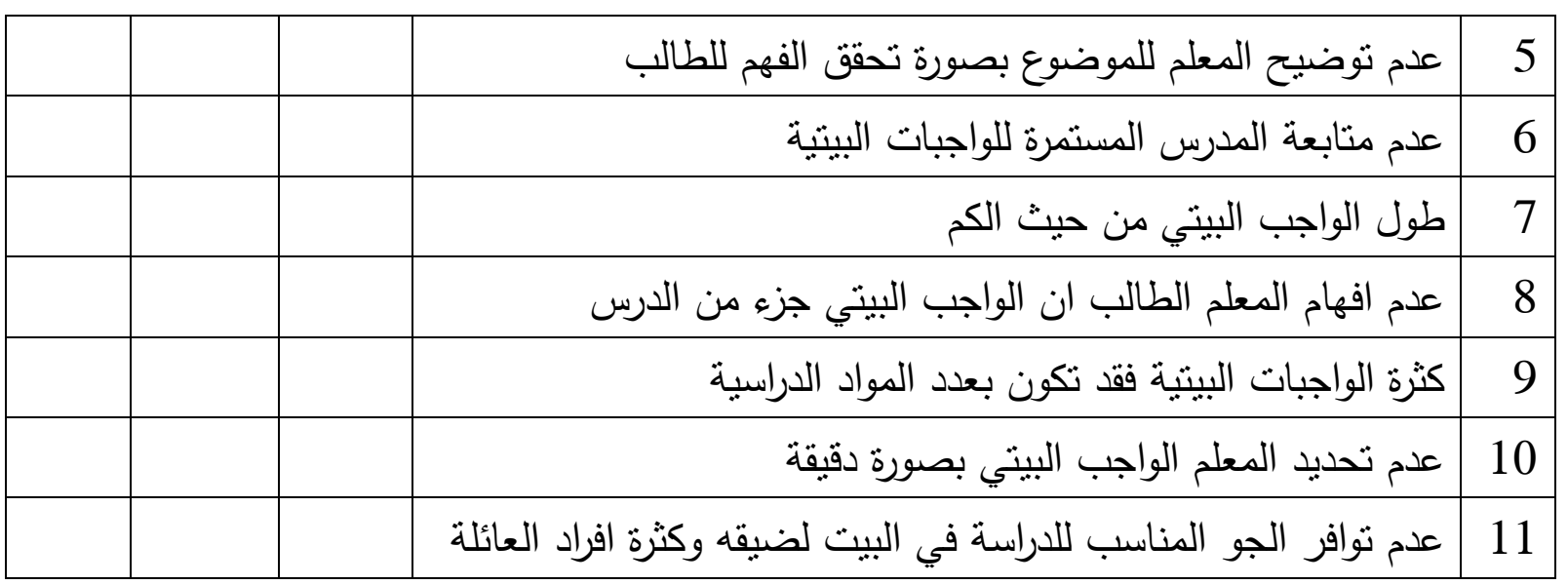

